\title{
Reactions of organolithium reagents with quinazoline derivatives
}

\author{
Gamal A. El-Hiti, ${ }^{a}{ }^{a} \dagger$ Amany S. Hegazy, ${ }^{a}$ Mohammad Hayal Alotaibi, ${ }^{b}$ and Mansour D. \\ Ajarim $^{b}$ \\ ${ }^{a}$ School of Chemistry, Cardiff University, Main Building, Park Place, Cardiff CF10 3AT, UK \\ ${ }^{b}$ Criminal Evidence, Ministry of Interior, Riyadh 11632, P.O. Box 86985, Saudi Arabia \\ Email:el-hitiga@cardiff.ac.uk \\ $\uparrow$ Permanent address: Chemistry Department, Faculty of Science, Tanta University, Tanta \\ 31527, Egypt
}

Dedicated to Professor Keith Smith on the occasion of his $65^{\text {th }}$ anniversary

\begin{abstract}
This review deals with directed and regioselective lithiation of various quinazoline derivatives by the use of alkyllithiums in anhydrous THF at low temperature. Reactions of the lithium reagents obtained from the lithiation reactions with a range of electrophiles give the corresponding substituted derivatives in high yields. The procedures are simple, efficient and general to provide derivatives which might be difficult to produce by other means. In some cases nucleophilic addition of alkyllithiums takes place to produce the corresponding addition products via 1,2- and 3,4-additions. In other cases nucleophilic substitution or halogen-lithium exchange reactions occur.
\end{abstract}

Keywords: $3 H$-Quinazolin-4-ones, directed ortho-lithiation, lateral lithiation, electrophilic substitution, alkyllithiums, nucleophilic addition

\section{Table of Contents}

1. Introduction

2. Directed Lithiation of Substituted 3H-Quinazolin-4-Ones

2.1. Directed lithiation of 3-acylamino-3H-quinazolin-4-ones

2.2. Directed lithiation of 3-aryl-3H-quinazolin-4-ones

2.3. Directed lithiation of chloro- and methoxy-3H-quinazolin-4-ones

2.4. Directed lithiation of tert-butylsulfinyl-2-tert-butyl-3H-quinazolin-4-one

2.5. Directed lithiation of 2-substituted $3 H$-quinazolin-4-ones

3. Directed Lithiation of Quinazoline Derivatives

3.1. Directed lithiation of 5-phenylsulfinyl-2-tert-butylquinazoline 
3.2. Directed lithiation of chloroquinazolines

3.3. Directed lithiation of methoxyquinazolines

4. Lateral Lithiation of 2-n-Alkylquinazoline Derivatives

4.1. Lateral lithiation of 3-acylamino-2- $n$-alkyl-3H-quinazolin-4-ones

4.2. Lateral lithiation 2 -n-alkyl-3-amino-3H-quinazolin-4-ones

4.3. Lateral lithiation of 3-substituted 2-methyl-3H-quinazolin-4-ones

4.4. Lateral lithiation of $2-n$-alkyl-3H-quinazolin-4-ones

4.5. Lateral lithiation 2-n-alkyl-3H-quinazolin-4-thiones

4.6. Lateral lithiation of 4-substituted $2-n$-alkylquinazolines

5. Bromine-Lithium Exchange of 6-Bromo-3H-Quinazolin-4-One

6. Addition of Alkyllithiums to Substituted Quinazoline Derivatives

6.1. Addition of alkyllithiums to 3-acylamino-3H-quinazolin-4-ones

6.2. Addition of alkyllithiums to 6-substituted $3 H$-quinazolin-4-ones

6.3. Addition of alkyllithiums to $3 H$-quinazolin-4-thiones

6.4. Addition of alkyllithiums to substituted quinazolines

\section{Conclusions}

8. References

\section{Introduction}

Regioselective synthesis of ortho-disubstituted aromatics is one of the classical problems in synthetic chemistry. Simple electrophilic substitution usually takes place under forcing conditions in the presence of a catalyst and often leads to various isomers and polysubstituted aromatics. $^{1,2}$ A number of alternative approaches have therefore been developed for regioselective ortho-disubstitution, and lithiation followed by electrophilic substitution is one of the most recognized and efficient. ${ }^{3-16}$

Directed lithiation of aromatic compounds $\mathbf{1}$ comprises deprotonation of a site ortho to a substituent that possesses a heteroatom (e.g. oxygen, nitrogen or sulfur) by use of a base. ${ }^{17-44}$ Such a substituent is known as a directing metallation group (DMG). The base, normally an alkyllithium reagent, leads to an ortho-lithiated species 3 (Scheme 1). Treatment of 3 with electrophilic reagents produces ortho-disubstituted products 4. ${ }^{45-55}$ Apparently, complexation occurs between the substituent group (DMG) and the lithium reagent prior to lithiation to give $\mathbf{2}$, and this serves to bring the lithium reagent into closer proximity with the ortho proton, which is then selectively removed. ${ }^{56}$

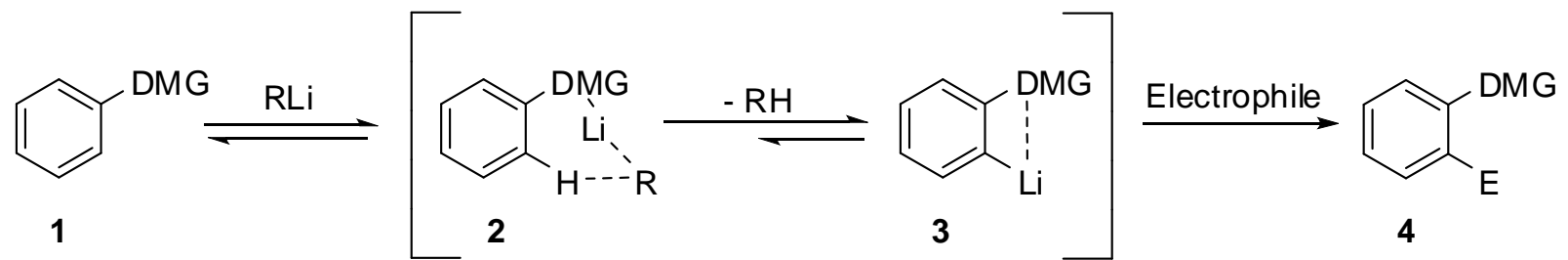

Scheme 1. Directed lithiation and substitution of aromatic compounds $\mathbf{1 .}$ 
For a successful deprotonation to occur, the DMG must possess the somewhat contrary properties of being a good coordinating site for the lithium reagent and a poor electrophilic site for attack by the lithium reagent. The rate and regioselectivity of ortho-lithiation seems to be controlled not only by coordination between the lithium reagent and the heteroatom of the DMG but also by the acidity of the proton at the ortho-position. ${ }^{12}$ It is not clear which factor is the principal driving force in ortho-lithiation. However, both of them could play a role for lithiation to be successful. For example, strong activators (DMG) tend to have a mixture of the basic requirements for good coordination to lithium reagent and the electron-withdrawing properties required to cause the ortho-protons to become acidic enough to encourage deprotonation efficiently and rapidly.

Groups that encourage such ortho-lithiation include: strong activators, $\mathrm{SO}_{2} \mathrm{NR}_{2}, \mathrm{NHCOR}$, $\mathrm{CONR}_{2}, \mathrm{CSNHR}, \mathrm{CONHR}, \mathrm{OCONR}_{2}, \mathrm{CO}_{2} \mathrm{R}, \mathrm{CH}_{2} \mathrm{NHCOR}, \mathrm{CH}_{2} \mathrm{NHR}, \mathrm{OCH}_{2} \mathrm{OMe}$; moderate activators, $\mathrm{OR}, \mathrm{NR}_{2}, \mathrm{SR}, \mathrm{CF}_{3}, \mathrm{~F}$; and weak activators, $\mathrm{CH}_{2} \mathrm{OH}, \mathrm{CH}(\mathrm{OR})_{2} .{ }^{12-16}$ The rapid expansion of the list of functionalities capable of directing lithiation has made this approach an important strategy for the synthesis of various regiospecifically substituted benzenes and heterocycles. ${ }^{57-64}$

The addition of organolithium reagents to the imine bond of pyridine and related nitrogen heterocycles is a well-established reaction. ${ }^{65-67}$ In particular, pyridine and quinoline undergo 1,2-addition on reaction with alkyllithiums. ${ }^{68}$ Also, some fluoroquinolines undergo exclusive addition with butyllithium (BuLi), but in the cases of 2-fluoro- and 7-fluoroquinolines competitive lithiation takes place at the 3 and 8-positions, respectively. ${ }^{69}$ However, these reactions become completely chemoselective for lithiation by the use of lithium diisopropylamide (LDA) at low temperature. The high reactivity of diazines towards nucleophiles makes the lithiation of such compounds even more difficult than that of most heterocycles. However, successful lithiation of diazines has been achieved by the use of less nucleophilic lithium reagents such as LDA or lithium 2,2,6,6-tetramethylpiperidine (LTMP). ${ }^{56,70}$

The synthesis of quinazoline derivatives has attracted the attention of chemists and has importance in medicinal chemistry because of the pharmacological applications for this heterocyclic ring system. ${ }^{71-81}$ Also, quinazoline derivatives are important intermediates in the synthesis of a variety of valuable heterocyclic compounds. ${ }^{82-86}$ Therefore, methods for the syntheses and/or modification of this ring system are always of interest. As part of our continuing interest in quinazoline chemistry ${ }^{87-101}$ and in lithiation chemistry, ${ }^{102-113}$ we have previously reported on the modification of the quinazoline ring system via lithiation and the organolithium reagents obtained from such reactions are very useful intermediates for the synthesis of substituted quinazoline derivatives that might be difficult to prepare by other means. ${ }^{114}$ This review will concentrate on the work published in the general area of directed and regioselective ring-lithiation of various quinazoline derivatives. Also, it will discuss the lateral lithiation of various $2-n$-alkylquinoxalines and their thione derivatives as well as the nucleophilic addition of alkyllithiums at the imine bonds of such ring systems. 


\section{Directed Lithiation of 3H-Quinazolin-4-Ones}

Directed lithiation of $3 \mathrm{H}$-quinazolin-4-one derivatives, containing a DMG at the 3-position (see sub-sections below), has been investigated by the use of hindered lithium reagents such as LDA at low temperature in anhydrous tetrahydrofuran (THF). ${ }^{115-118}$ Lithiation is regioselective at the 2-position to produce the corresponding lithium reagents that on reactions with electrophiles give the corresponding 2-substituted derivatives in high yields. Also, directed lithiation of some substituted $3 \mathrm{H}$-quinazolin-4-ones takes place on the benzenoid ring next to chloro, methoxy, tert-butylsulfinyl or phenylsulfinyl groups. ${ }^{19-122}$

\subsection{Directed Lithiation of 3-Acylamino-3H-Quinazolin-4-Ones}

Directed lithiation of 3-acylamino-3H-quinazolin-4-ones 5 was achieved by the use of LDA in anhydrous THF at $-78{ }^{\circ} \mathrm{C}$ for $1 \mathrm{~h}$ under nitrogen and the lithiation reaction was regioselective at the 2-position (Scheme 2). ${ }^{115}$ Two molar equivalents of LDA were used, the first to remove the $\mathrm{NH}$ proton to give the monolithium reagents $\mathbf{6}$ as yellowish solutions and the second to remove the hydrogen from the 2-position to form the dilithium reagents $\mathbf{7}$ as yellowish brown solutions (Scheme 2). Reactions of the dilithium reagents 7 with various electrophiles in THF at $-78{ }^{\circ} \mathrm{C}$ for 4 hours afforded the corresponding 2-substituted 3-acylamino-3H-quinazolin-4-ones 8-19 in very good yields (Table 1$){ }^{115}$

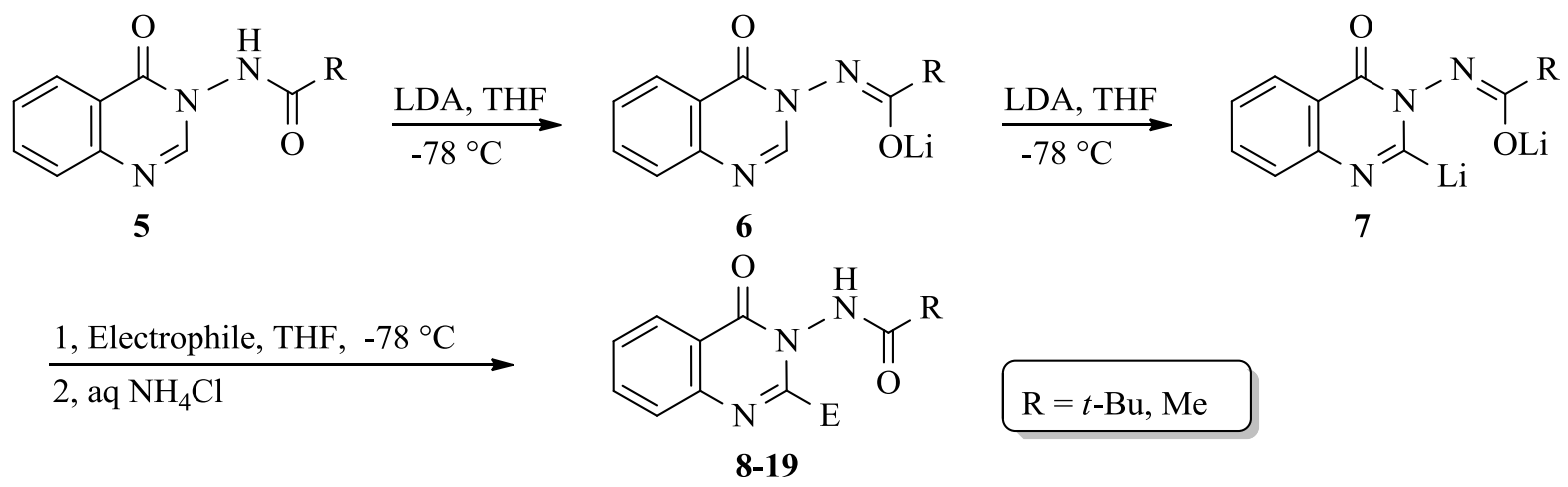

Scheme 2. Directed lithiation and substitution of 5.

No deprotonation of the methyl group occurred for the case of compound $\mathbf{5 b}(\mathrm{R}=\mathrm{Me})$ despite the acidic character of the methyl protons. ${ }^{123,124}$ Such side reactions took place with simple acetanilides and account for the preferred use of the pivaloylamino group in directed lithiation reactions. ${ }^{17-20}$

Reactions with excess iodomethane resulted in excellent yields of 2-alkylated products, but as mixtures of 2-methyl-, 2-ethyl-, and 2-(1-methylethyl)-3H-quinazolin-4-ones. ${ }^{115}$ The authors concluded that the 2-methyl-3H-quinazolin-4-ones 8 and $\mathbf{1 4}$ initially produced underwent lithiation by the excess LDA present in the reaction mixture and were then methylated to give the 2-ethyl derivatives $\mathbf{2 0}$ and $\mathbf{2 2}$, respectively. These in turn reacted further to give the 
2-(1-methylethyl) derivatives $\mathbf{2 1}$ and $\mathbf{2 3}$, respectively. ${ }^{115}$ The authors did not attempt to optimize the yield of any individual products from these reactions, but it is likely that control of the total amount of LDA and/or iodomethane would allow the production of 2-methyl derivatives $\mathbf{8}$ and 14 without formation of any other alkylated products 20-23 (Figure 1).

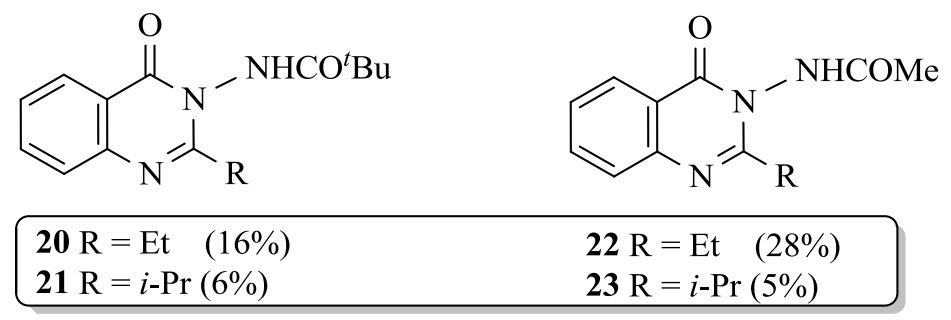

Figure 1. Structures of compounds 20-23.

Table 1. Synthesis of 2-substituted $3 H$-quinazolin-4-ones 8-19 according to Scheme $2^{115}$

\begin{tabular}{|c|c|c|c|c|}
\hline Product & $\mathrm{R}$ & Electrophile & $\mathrm{E}$ & Yield $(\%)^{\mathrm{a}}$ \\
\hline 8 & $t-\mathrm{Bu}$ & MeI & $\mathrm{Me}$ & $67^{\mathrm{b}}$ \\
\hline 9 & $t-\mathrm{Bu}$ & $\mathrm{D}_{2} \mathrm{O}$ & $\mathrm{D}$ & 88 \\
\hline 10 & $t-\mathrm{Bu}$ & $\mathrm{Ph}_{2} \mathrm{CO}$ & $\mathrm{Ph}_{2} \mathrm{C}(\mathrm{OH})$ & 85 \\
\hline 11 & $t-\mathrm{Bu}$ & PhCOMe & $\mathrm{PhC}(\mathrm{OH})(\mathrm{Me})$ & 85 \\
\hline 12 & $t-\mathrm{Bu}$ & $\left(\mathrm{CH}_{2}\right)_{5} \mathrm{CO}$ & $\left(\mathrm{CH}_{2}\right)_{5} \mathrm{C}(\mathrm{OH})$ & 87 \\
\hline 13 & $t-\mathrm{Bu}$ & $\mathrm{PhNCO}$ & PhNHCO & 76 \\
\hline 14 & $\mathrm{Me}$ & MeI & $\mathrm{Me}$ & $59^{c}$ \\
\hline 15 & $\mathrm{Me}$ & $\mathrm{D}_{2} \mathrm{O}$ & $\mathrm{D}$ & 79 \\
\hline 16 & $\mathrm{Me}$ & $\mathrm{Ph}_{2} \mathrm{CO}$ & $\mathrm{Ph}_{2} \mathrm{C}(\mathrm{OH})$ & 80 \\
\hline 17 & $\mathrm{Me}$ & PhCOMe & $\mathrm{PhC}(\mathrm{OH})(\mathrm{Me})$ & 80 \\
\hline 18 & $\mathrm{Me}$ & $\left(\mathrm{CH}_{2}\right)_{5} \mathrm{CO}$ & $\left(\mathrm{CH}_{2}\right)_{5} \mathrm{C}(\mathrm{OH})$ & 81 \\
\hline 19 & $\mathrm{Me}$ & $\mathrm{PhNCO}$ & PhNHCO & 80 \\
\hline
\end{tabular}

a Yield of isolated product after crystallization from ethyl acetate.

b-Ethyl-3-pivaloylamino-3H-quinazolin-4-one 20 and 2-(1-methylethyl)-3-pivaloylamino-3Hquinazolin-4-one 21 (Figure 1) were produced as side products in 16 and 6\% yields, respectively. '3-Acetylamino-2-ethyl-3H-quinazolin-4-one 22 and 3-acetylamino-2-(1-methylethyl)-3Hquinazolin-4-one 23 (Figure 1) were produced as side products in 28 and 5\% yields, respectively.

Reactions of the dilithium reagents $\mathbf{7}$, obtained from lithiation of $\mathbf{5}$, with iodine took place in a different manner involving oxidative dimerisation. 6,13-Dipivaloyl-1,2,4,5-tetrazino[3,2- $b$ :6,5$b^{\prime}$ ']bisquinazolin-7,14(6aH,13aH)-dione $\mathbf{2 4}$ and 6,13-diacetyl-1,2,4,5-tetrazino[3,2- $b$ :6,5$b^{\prime}$ ']bisquinazolin-7,14(6aH,13aH)-dione 25 were obtained in 67 and $66 \%$ yields, respectively (Scheme 3) instead of 2-iodo-3H-quinazolin-4-ones. ${ }^{115}$ 
<smiles>[R]C(=O)Nn1cnc2ccccc2c1=O</smiles>

5

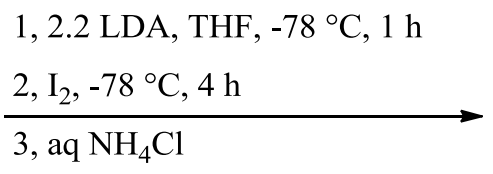<smiles></smiles>

$24 \mathrm{R}=t$ - $\mathrm{Bu}(67 \%)$

$25 \mathrm{R}=\mathrm{Me} \quad(66 \%)$

Scheme 3. Directed lithiation of 5 followed by reactions with iodine.

Directed lithiation of $\mathbf{5 a}$ with three molar equivalents of LDA in THF at $-78^{\circ} \mathrm{C}$ for one hour followed by reaction with carbon monoxide at $0{ }^{\circ} \mathrm{C}$ for two hours gave a $77 \%$ isolated yield of a mixture of azetidinone derivative 26 and indole derivative 27 (Scheme 4). ${ }^{116}$ Both products involved the incorporation of a diisopropylamide unit from the LDA used for lithiation as well as carbon monoxide. Compound $\mathbf{2 6}$ was obtained due to reaction of the lithium intermediate obtained with one molar equivalent of carbon monoxide, while compound 27 involved uptake of two molar equivalents of carbon monoxide. The mechanism of the formation of $\mathbf{2 6}$ and $\mathbf{2 7}$ has not been investigated.<smiles>CCCCNC(=O)NNC(=O)c1ccccc1NC1C(=O)N(CCC)C1(C)C</smiles>

Scheme 4. Directed lithiation and carbonylation of $\mathbf{5 a}$.

\subsection{Directed lithiation of 3-aryl-3H-quinazolin-4-ones}

Lithiation of 3-(2-(diphenylphosphino)-4,6-dimethylphenyl)-3H-quinazolin-4-one 28 took place rapidly with one molar equivalent of LDA in THF at $-78{ }^{\circ} \mathrm{C}$ under argon to give the corresponding 2-lithium reagent 29 as a yellow solution (Scheme 5), which was found to be unstable at temperature above $-20{ }^{\circ} \mathrm{C} .{ }^{117}$ Reaction of 29 with chlorodiphenylphosphine $\left(\mathrm{PPh}_{2} \mathrm{Cl}\right)$, solid sulfur $\left(\mathrm{S}_{8}\right)$, and dimethyl disulfide (MeSSMe) in THF at $-78{ }^{\circ} \mathrm{C}$ for $1 \mathrm{~h}$ gave 2 -substituted derivatives 30-32 in 84-88\% yields (Scheme 5). ${ }^{117}$ 
<smiles>Cc1cc(C)c(-n2cnc3ccccc3c2=O)c(-c2ccccc2)c1</smiles>

28<smiles>Cc1cc(C)c(-n2c([AlH2])nc3ccccc3c2=O)c(-c2ccccc2)c1</smiles>

29<smiles>Cc1cc(C)c(-n2c(F)nc3ccccc3c2=O)c(-c2ccccc2)c1</smiles>

$30 \mathrm{E}=\mathrm{PPh}_{2}(88 \%)$

$31 \mathrm{E}=\mathrm{SH} \quad(84 \%)$

$32 \mathrm{E}=\mathrm{SMe}(88 \%)$

Scheme 5. Directed lithiation and substitution of 28.

Lithiation of methyl 2-(4-oxo-4H-quinazolin-3-yl)benzoate 33 with LDA (1.5 molar equivalents) in THF at $-78{ }^{\circ} \mathrm{C}$ for two hours gave the corresponding 2-lithium derivative $\mathbf{3 4}$ as a reddish solution. ${ }^{118}$ The lithium reagent $\mathbf{3 4}$ underwent intramolecular cyclisation at room temperature to give indolo[2,1-b]quinazoline-6,12-dione 35 in $81 \%$ yield (Scheme 6 ). ${ }^{118}$<smiles>COC(=O)c1ccccc1-n1cnc2ccccc2c1=O</smiles>

Scheme 6. Directed lithiation of $\mathbf{3 3}$ with LDA followed by intramolecular cyclisation.

\subsection{Directed lithiation of chloro- and methoxy-3H-quinazolin-4-ones}

Various attempts have been made to lithiate 6,8-dichloro- $3 H$-quinazolin-4-one. ${ }^{119}$ However, none of the conditions tried was successful; instead starting material or a degraded product was obtained. ${ }^{119}$ On the other hand, lithiation of 7-chloro- and 6,7-dimethoxyquinazolines 36 took place at the 8-position by the use of a mixture of $n$-BuLi (one molar equivalent) and LTMP (four molar equivalents) for one hour at $-78{ }^{\circ} \mathrm{C}$ to give dilithium derivative 37 (Scheme 7). ${ }^{119}$ Reactions of $\mathbf{3 7}$ with acetaldehyde and benzaldehyde gave 8-substituted products 38-41 (Scheme 7) in 50-95\% yield (Table 2) along with a small quantity of starting material $36 .{ }^{119}$ The yields were high for 7-chloro-3H-quinazolin-4-one $36\left(\mathrm{R}^{1}=\mathrm{H}, \mathrm{R}^{2}=\mathrm{Cl}\right)$ and moderate for 6,7dimethoxy-3H-quinazolin-4-one $36\left(\mathrm{R}^{1}=\mathrm{R}^{2}=\mathrm{OMe}\right)$.

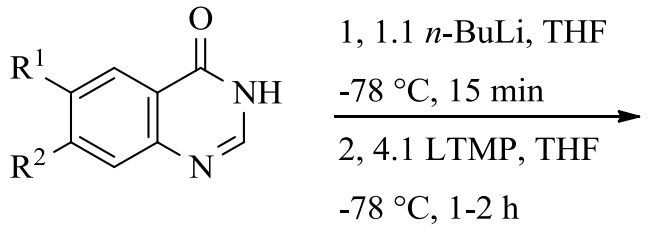

36<smiles>[R]c1cc2c(O[AlH2])ncnc2c([AlH])c1[R]</smiles>

37

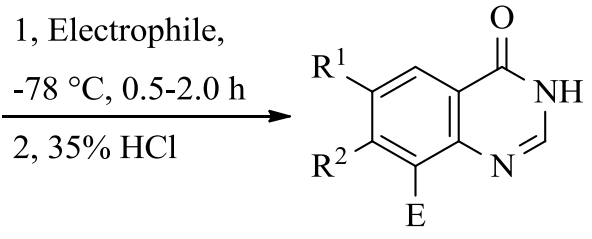

38-41

Scheme 7. Directed lithiation and substitution of $\mathbf{3 6 .}$ 
Table 2. Synthesis of 8 -substituted $3 H$-quinazolin-4-ones $\mathbf{3 8 - 4 1}$ according to Scheme $7^{119}$

\begin{tabular}{cccccc}
\hline Product & $\mathrm{R}^{1}$ & $\mathrm{R}^{2}$ & Electrophile & $\mathrm{E}$ & ${\text { Yield }(\%)^{\mathrm{a}}}^{\mathrm{a}}$ \\
\hline $\mathbf{3 8}$ & $\mathrm{H}$ & $\mathrm{Cl}$ & $\mathrm{MeCHO}$ & $\mathrm{MeCH}(\mathrm{OH})$ & 73 \\
$\mathbf{3 9}$ & $\mathrm{H}$ & $\mathrm{Cl}$ & $\mathrm{PhCHO}$ & $\mathrm{PhCH}(\mathrm{OH})$ & 95 \\
$\mathbf{4 0}$ & $\mathrm{OMe}$ & $\mathrm{OMe}$ & $\mathrm{MeCHO}$ & $\mathrm{MeCH}(\mathrm{OH})$ & 50 \\
$\mathbf{4 1}$ & $\mathrm{OMe}$ & $\mathrm{OMe}$ & $\mathrm{PhCHO}$ & $\mathrm{PhCH}(\mathrm{OH})$ & 50 \\
\hline
\end{tabular}

${ }^{\mathrm{a}}$ Yield of isolated product after column chromatography.

\subsection{Directed lithiation of tert-butylsulfinyl-2-tert-butyl-3H-quinazolin-4-one}

The position of a tert-butylsulfinyl group on the $3 H$-quinazolin-4-one ring system was found to have an effect on the position of lithiation. For example, lithiation of 5-tert-butylsulfinyl-2-tertbutyl-3H-quinazolin-4-one was not successful using excess LTMP at $-78{ }^{\circ} \mathrm{C}$ and starting material along with tarry material were recovered. ${ }^{120}$ On the other hand, lithiation of 8-tertbutylsulfinyl-2-tert-butyl-3H-quinazolin-4-one $\mathbf{4 2}$ with LTMP at $-78{ }^{\circ} \mathrm{C}$ in THF was regioselective at the 7-position to give dilithium intermediate $\mathbf{4 3}$, which on reactions with $\mathrm{DCl}$ and 4-anisaldehyde gave 7-substituted derivatives $\mathbf{4 4}$ and $\mathbf{4 5}$ in 91 and $88 \%$ yields, respectively (Scheme 8). ${ }^{120}$

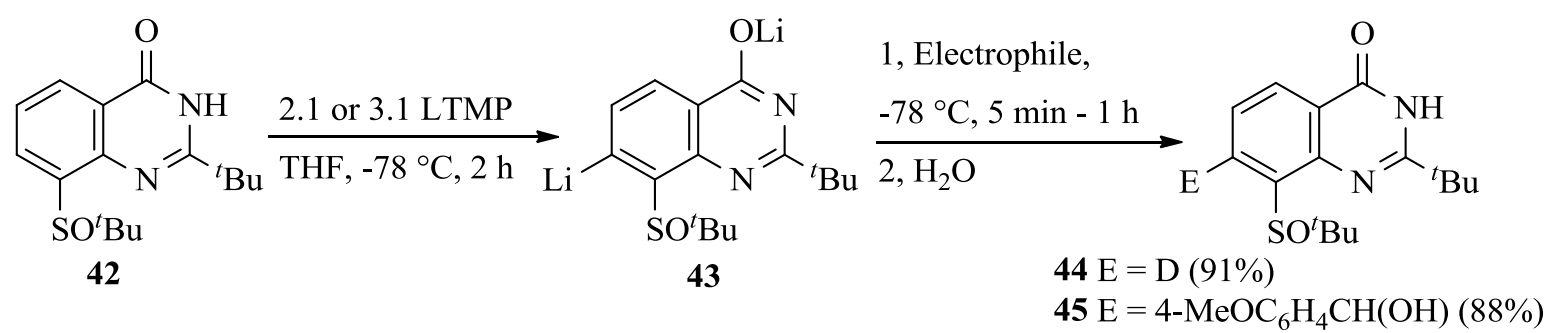

Scheme 8. Directed lithiation and substitution of $\mathbf{4 2}$.

\subsection{Directed lithiation of 2-substituted $3 H$-quinazolin-4-ones}

Lithiation of 2-tert-butyl-3H-quinazolin-4-one $\mathbf{4 6}$ was regioselective at the 5-position to give the dilithium intermediate $\mathbf{4 7}$ by the use of four molar equivalents of $s$ - $\mathrm{BuLi}$ in the presence of tetramethylethylenediamine (TMEDA) at $-20{ }^{\circ} \mathrm{C}$ in THF (Scheme 9). ${ }^{125}$ Reactions of $\mathbf{4 7}$ with a range of electrophiles at $-78{ }^{\circ} \mathrm{C}$ gave the corresponding 5 -substituted derivatives $48-53$ in $17-94 \%$ yields (Table 3 ). ${ }^{125}$

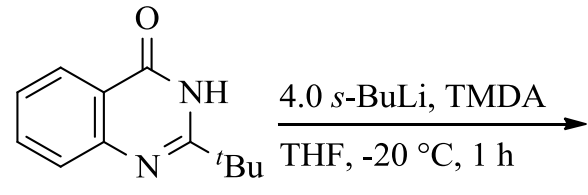

46

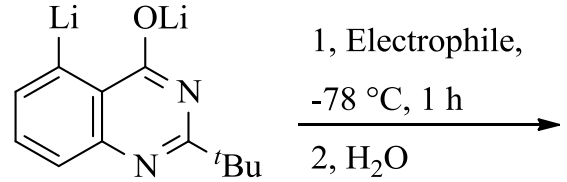

47<smiles>O=c1[nH]c(Br)nc2cccc(F)c12</smiles>

48-53

Scheme 9. Lithiation and substitution of $\mathbf{4 6 .}$ 
Table 3. Synthesis of 5-substituted $3 H$-quinazolin-4-ones $\mathbf{4 8 - 5 3}$ according to Scheme $9^{125}$

\begin{tabular}{cccc}
\hline Product & Electrophile & $\mathrm{E}$ & ${\text { Yield }(\%)^{\mathrm{a}}}^{\mathrm{a}}$ \\
\hline $\mathbf{4 8}$ & $\mathrm{MeCHO}$ & $\mathrm{MeCH}(\mathrm{OH})$ & 94 \\
$\mathbf{4 9}$ & $\mathrm{PhCHO}$ & $\mathrm{PhCH}(\mathrm{OH})$ & 92 \\
$\mathbf{5 0}$ & $\mathrm{PhSSPh}$ & $\mathrm{PhS}$ & 17 \\
$\mathbf{5 1}$ & $\mathrm{Bu} 3 \mathrm{SnCl}$ & $\mathrm{Bu} 3 \mathrm{Sn}$ & 50 \\
$\mathbf{5 2}$ & $\mathrm{I}_{2}$ & $\mathrm{I}$ & 37 \\
$\mathbf{5 3}$ & $\left({ }^{i} \mathrm{PrO}\right)_{3} \mathrm{~B}$ & $\mathrm{~B}(\mathrm{OH})_{2}$ & $68^{\mathrm{b}}$ \\
\hline
\end{tabular}

${ }^{a}$ Yield of isolated product after column chromatography.

${ }^{\mathrm{b}}$ Reaction was carried out at $-78{ }^{\circ} \mathrm{C}$ to room temperature for $15 \mathrm{~h}$.

Lithiation of 2-(quinolin-2-yl)-3H-quinazolin-4-one $\mathbf{5 4}$ with two molar equivalents of mesityllithium (MesLi) in THF at $-78{ }^{\circ} \mathrm{C}$ for 30 min gave the dilithium reagent $\mathbf{5 5}$ as a deep brown solution. ${ }^{126}$ Reaction of $\mathbf{5 5}$ with formaldehyde in THF at $-20{ }^{\circ} \mathrm{C}$ gave alcohol $\mathbf{5 6}$ in $86 \%$ yield (Scheme 10). ${ }^{126}$<smiles>O=c1[nH]c(-c2ccc3ccccc3n2)nc2ccccc12</smiles>

Scheme 10. Lithiation of $\mathbf{5 4}$ followed by reaction with formaldehyde.

\section{Directed Lithiation of Quinazoline Derivatives}

Directed lithiation and substitution of various quinazoline derivatives (see sub-sections below) has been achieved by the use of alkyllithiums followed by reactions with electrophiles to produce the corresponding substituted derivatives. ${ }^{120,121}$

\subsection{Directed lithiation of 5-phenylsulfinyl-2-tert-butylquinazoline}

Directed lithiation of 5-phenylsulfinyl-2-tert-butylquinazoline 57 with excess LTMP (two molar equivalents) took place at the 6-position to give the 6-lithium intermediate $\mathbf{5 8}$ which on reaction with $\mathrm{DCl}$ gave $\mathbf{5 9}$ in $86 \%$ yield (Scheme 11). ${ }^{120}$ 


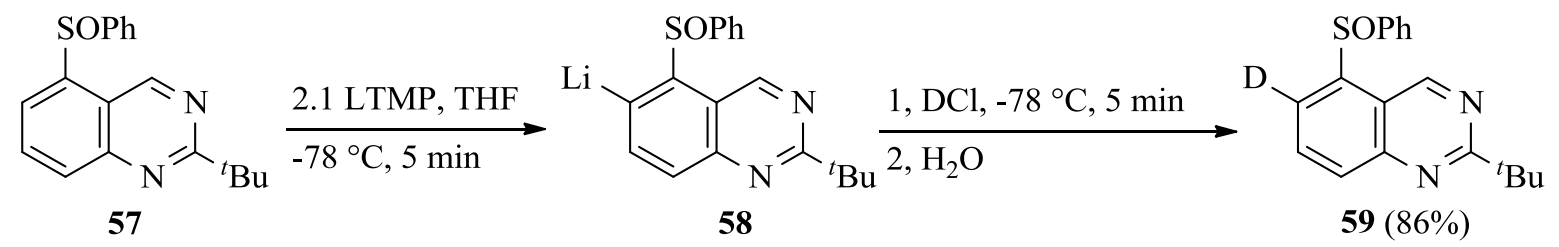

Scheme 11. Directed lithiation of $\mathbf{5 7}$ followed by reaction with DCl.

When the reaction was carried out with trimethylsilyl chloride (TMSCl) as the electrophile under conditions similar to those used in Scheme 11, 2-tert-butyl-5-(phenylsulfinyl)-6(trimethylsilyl)quinazoline $\mathbf{6 0}$ and a cyclized product $\mathbf{6 1}$ (Figure 2) were obtained in 37\% yield each. ${ }^{120}$ Compound $\mathbf{6 1}$ was obtained as a result of a second ortho-directed lithiation on the orthoposition of the phenyl ring followed by a nucleophilic addition of the lithium derivative at the 4-position of the quinazoline ring and finally aromatization by air oxidation. ${ }^{120}$
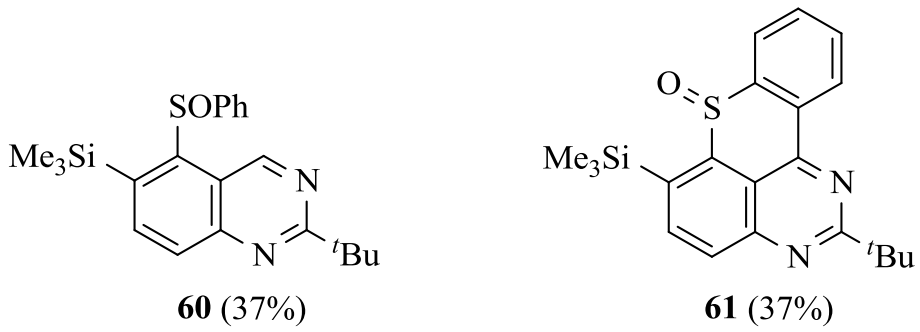

Figure 2. Structures of compounds 60 and 61.

\subsection{Directed lithiation of chloroquinazolines}

Lithiation of 4-substituted 6-chloroquinazoline 62a (Scheme 12; $\mathrm{X}=\mathrm{Cl}, \mathrm{Y}=\mathrm{H} ; \mathrm{R}=\mathrm{OMe}$, $\left.\mathrm{O}\left(\mathrm{CH}_{2}\right)_{2} \mathrm{OMe}, \mathrm{NEt}_{2}\right)$ with LTMP (2.2 molar equivalents) in THF at $-78{ }^{\circ} \mathrm{C}$ for 0.5 hour gave the corresponding lithium derivative 63a in which lithiation took place at the 8-position. ${ }^{121}$ Reactions of 63a with a range of electrophiles at $-78^{\circ} \mathrm{C}$ for $0.5-2.0$ hours gave the corresponding 8 -substituted quinazolines 64-69 in low to moderate yields (Table 4). ${ }^{121}$

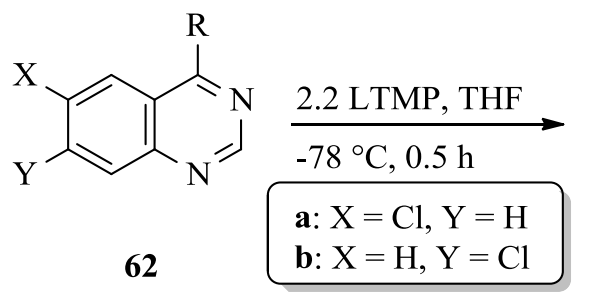<smiles>[Y]c1cc2c([R])ncnc2c([AlH2])c1[Y]</smiles>

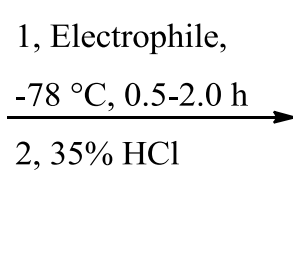<smiles>[X]c1cc2c([R])ncnc2c(F)c1[Y]</smiles>

Scheme 12. Directed lithiation and substitution of 62 .

Similarly, lithiation of 7-chloro-4-methoxyquinazoline 62b (Scheme 12; $\mathrm{X}=\mathrm{H}, \mathrm{Y}=\mathrm{Cl}, \mathrm{R}=$ $\mathrm{OMe}$ ) with LTMP in THF at $-78{ }^{\circ} \mathrm{C}$ for 0.5 hour gave the corresponding lithium derivative $\mathbf{6 3 b}$ 
which, on reactions with various electrophiles, gave the corresponding 8-substituted quinazolines 70-74 in $32-85 \%$ yields (Table 4). ${ }^{121}$ Starting material was recovered from reactions that gave low yields.

Table 4. Synthesis of 8-substituted quinazolines 64-74 according to Scheme $12^{121}$

\begin{tabular}{ccccccc}
\hline Product & $\mathrm{X}$ & $\mathrm{Y}$ & $\mathrm{R}$ & Electrophile & $\mathrm{E}$ & ${\text { Yield }(\%)^{\mathrm{a}}}^{\mathbf{6}}$ \\
\hline $\mathbf{6 4}$ & $\mathrm{Cl}$ & $\mathrm{H}$ & $\mathrm{OMe}$ & $\mathrm{MeCHO}$ & $\mathrm{MeCH}(\mathrm{OH})$ & 50 \\
$\mathbf{6 5}$ & $\mathrm{Cl}$ & $\mathrm{H}$ & $\mathrm{OMe}$ & $\mathrm{PhCHO}$ & $\mathrm{PhCH}(\mathrm{OH})$ & 19 \\
$\mathbf{6 6}$ & $\mathrm{Cl}$ & $\mathrm{H}$ & $\mathrm{OMe}$ & $\mathrm{I}_{2}$ & $\mathrm{I}$ & $25^{\mathrm{b}}$ \\
$\mathbf{6 7}$ & $\mathrm{Cl}$ & $\mathrm{H}$ & $\mathrm{OMe}$ & $\mathrm{Me}_{3} \mathrm{SiCl}$ & $\mathrm{Me} \mathrm{Si}_{3}$ & $35^{\mathrm{b}, \mathrm{c}}$ \\
$\mathbf{6 8}$ & $\mathrm{Cl}$ & $\mathrm{H}$ & $\mathrm{O}\left(\mathrm{CH}_{2}\right)_{2} \mathrm{OMe}$ & $\mathrm{MeCHO}$ & $\mathrm{MeCH}(\mathrm{OH})$ & 29 \\
$\mathbf{6 9}$ & $\mathrm{Cl}$ & $\mathrm{H}$ & $\mathrm{NEt}_{2}$ & $\mathrm{MeCHO}$ & $\mathrm{MeCH}(\mathrm{OH})$ & 55 \\
$\mathbf{7 0}$ & $\mathrm{H}$ & $\mathrm{Cl}$ & $\mathrm{OMe}$ & $\mathrm{MeCHO}$ & $\mathrm{MeCH}(\mathrm{OH})$ & 85 \\
$\mathbf{7 1}$ & $\mathrm{H}$ & $\mathrm{Cl}$ & $\mathrm{OMe}$ & $\mathrm{PhCHO}$ & $\mathrm{PhCH}(\mathrm{OH})$ & 73 \\
$\mathbf{7 2}$ & $\mathrm{H}$ & $\mathrm{Cl}$ & $\mathrm{OMe}$ & $\mathrm{MeI}$ & $\mathrm{Me}$ & $40^{\mathrm{d}, \mathrm{e}}$ \\
$\mathbf{7 3}$ & $\mathrm{H}$ & $\mathrm{Cl}$ & $\mathrm{OMe}$ & $\mathrm{I}_{2}$ & $\mathrm{I}$ & $32^{\mathrm{be}, \mathrm{f}}$ \\
$\mathbf{7 4}$ & $\mathrm{H}$ & $\mathrm{Cl}$ & $\mathrm{OMe}$ & $\mathrm{Me}_{3} \mathrm{SiCl}$ & $\mathrm{Me}_{3} \mathrm{Si}$ & $40^{\mathrm{c}, \mathrm{e}}$ \\
\hline
\end{tabular}

${ }^{\mathrm{a}}$ Yield of isolated product after column chromatography.

${ }^{b}$ Yield after purification by column chromatography and sublimation.

'Obtained with the in situ trapping technique in which 62a and trimethylsilyl chloride were simultaneously added to the LTMP solution.

${ }^{\mathrm{d}}$ 7-Chloro-8-ethyl-4-methoxyquinazoline 75 (Figure 4) was obtained as a side product in $8 \%$ yield due to lithiation and methylation of methylated product $\mathbf{7 2}$.

${ }^{\mathrm{e}}$ Starting material 62b was recovered (31-55\%).

${ }^{\mathrm{f}}$ Reaction was carried out with 1.3 molar equivalents LTMP.<smiles>CCc1c(Cl)ccc2c(OC)ncnc12</smiles>

$75(8 \%)$

Figure 3. Structure of compound $\mathbf{7 5 .}$

Lithiation of 6,8-dichloro-4-methoxyquinazoline 76 with 2.2 molar equivalents of LTMP in THF at $-78{ }^{\circ} \mathrm{C}$ for $2.5 \mathrm{~h}$ gave 7 -lithio derivative 77 (Scheme 13) that on reactions with various electrophiles gave 7 -substituted quinazolines $\mathbf{7 8 - 8 3}$ in $88-93 \%$ yield (Table 5). ${ }^{121}$ 

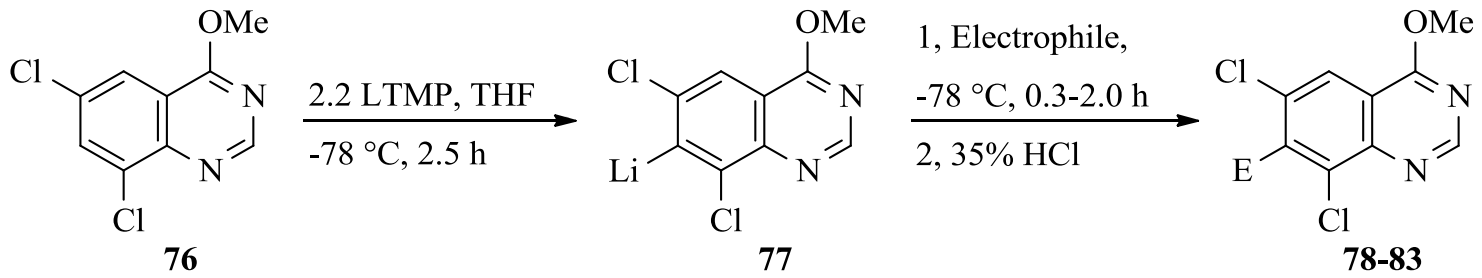

Scheme 13. Directed lithiation and substitution of $\mathbf{7 6 .}$

Table 5. Synthesis of 7-substituted quinazolines 78-83 according to Scheme $13^{121}$

\begin{tabular}{cccc}
\hline Product & Electrophile & $\mathrm{E}$ & ${\text { Yield }(\%)^{\mathrm{a}}}^{\mathrm{a}}$ \\
\hline $\mathbf{7 8}$ & $\mathrm{MeCHO}$ & $\mathrm{MeCH}(\mathrm{OH})$ & 93 \\
$\mathbf{7 9}$ & $\mathrm{PhCHO}$ & $\mathrm{PhCH}(\mathrm{OH})$ & 92 \\
$\mathbf{8 0}$ & $\mathrm{I}_{2}$ & $\mathrm{I}$ & 90 \\
$\mathbf{8 1}$ & $\mathrm{Me}_{3} \mathrm{SiCl}$ & $\mathrm{Me}_{3} \mathrm{Si}$ & $88^{\mathrm{b}}$ \\
$\mathbf{8 2}$ & $\mathrm{MeI}$ & $\mathrm{Me}$ & 93 \\
$\mathbf{8 3}$ & $\mathrm{EtOD} / \mathrm{DCl}$ & $\mathrm{D}$ & 88 \\
\hline
\end{tabular}

${ }^{a}$ Yield of isolated product after column chromatography.

${ }^{b}$ Obtained with the in situ trapping technique in which $\mathbf{7 6}$ and $\mathrm{Me}_{3} \mathrm{SiCl}$ were simultaneously added to the LTMP solution.

Lithiation of 8-chloro-2,4,6,7-tetramethoxyquinazoline 84 with LTMP was not successful under different reaction conditions. ${ }^{121}$ However, use of $n$ - $\mathrm{BuLi}$ (two molar equivalents) at $-78^{\circ} \mathrm{C}$ for 40 minutes followed by reaction with acetaldehyde for 30 minutes gave a mixture of $\mathbf{8 5}$ and 86 in 64 and 26\% yields, respectively (Scheme 14). ${ }^{121}$

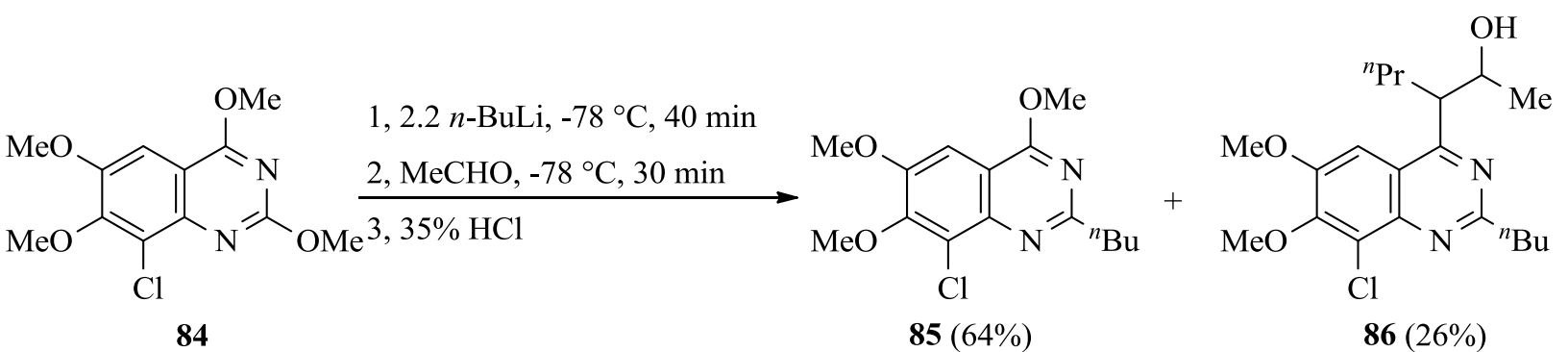

Scheme 14. Reaction of 84 with $n$-BuLi followed by reaction with acetaldehyde.

Compound 85 was obtained as a result of replacement of the methoxy group at the 2-position by a butyl group from $n$-BuLi. While compound $\mathbf{8 6}$ was obtained due to replacement of the two methoxy groups at the 2- and 4-positions by two butyl groups from $n$-BuLi followed by lithiation 
at the $\alpha$-position of the butyl group at the 4-position and finally reaction of the lithium reagent obtained with acetaldehyde.

On the other hand, treatment of $\mathbf{8 4}$ with $t$-BuLi (two molar equivalents) followed by reaction with acetaldehyde under conditions similar to those used in Scheme 14 gave a mixture of $\mathbf{8 7}$ and $\mathbf{8 8}$ in 32 and $39 \%$ yields, respectively (Scheme 15). ${ }^{121}$<smiles>COc1nc(OC)c2cc(OC)c(OC)c(Cl)c2n1</smiles>

84<smiles>COc1cc2c(CC(C)C)nc(CC(C)C)nc2c(Cl)c1OC</smiles>

$87(32 \%)$<smiles>COc1cc2c(OC)nc(CC(C)C)nc2c(C(C)O)c1OC</smiles>

Scheme 15. Reaction of 84 with $t$-BuLi in THF followed by reaction with acetaldehyde.

Compound 87 was obtained due to replacement of the two methoxy groups at the 2- and 4-positions by two tert-butyl groups from $t$-BuLi. While compound $\mathbf{8 8}$ was obtained due to replacement of the methoxy group at the 2-position by a tert-butyl group from $t$-BuLi followed by chlorine-lithium exchange to produce the corresponding 8 -lithium derivative that reacted with acetaldehyde. $^{121}$

\subsection{Directed lithiation of methoxyquinazolines}

Lithiation of 2,4,6,7-tetramethoxyquinazoline 89 with two molar equivalents of $n$-BuLi at $-78^{\circ} \mathrm{C}$ took place at the 8-position to give the 8-lithium intermediate 90 (Scheme 16). ${ }^{121}$ Reactions of 90 with various electrophiles afforded the corresponding 8-substituted derivatives 91-96 in 51-97\% yields (Table 6). ${ }^{121}$

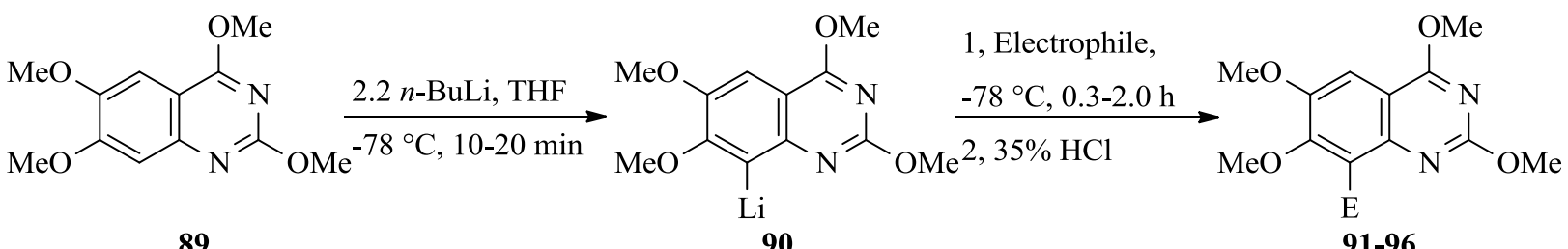

Scheme 16. Directed lithiation and substitution of 89. 
Table 6. Synthesis of 8-substituted quinazolines 91-96 according to Scheme $16^{121}$

\begin{tabular}{cccc}
\hline Product & Electrophile & $\mathrm{E}$ & ${\text { Yield }(\%)^{\mathrm{a}}}^{\mathrm{a}}$ \\
$\mathbf{9 1}$ & $\mathrm{MeCHO}$ & $\mathrm{MeCH}(\mathrm{OH})$ & 97 \\
92 & $\mathrm{PhCHO}$ & $\mathrm{PhCH}(\mathrm{OH})$ & 99 \\
93 & $\mathrm{MeI}$ & $\mathrm{Me}$ & $51^{\mathrm{b}}$ \\
94 & $\mathrm{EtOD} / \mathrm{DCl}$ & $\mathrm{D}$ & 96 \\
95 & $\mathrm{I}_{2}$ & $\mathrm{I}$ & 89 \\
96 & $\mathrm{C}_{2} \mathrm{Cl}_{6}$ & $\mathrm{Cl}$ & 90 \\
\hline
\end{tabular}

${ }^{a}$ Yield of isolated product after column chromatography.

${ }^{\mathrm{b}}$ Starting material $\mathbf{8 9}$ was recovered.

Treatment of 6,7-dimethoxy-4-phenylaminoquinazoline 97 with LTMP (5 molar equivalents) at $-78{ }^{\circ} \mathrm{C}$ for $2 \mathrm{~h}$ gave the corresponding 8 -lithium derivative 98 which on reactions with acetaldehyde and benzaldehyde afforded 8-substituted derivatives 99 and $\mathbf{1 0 0}$ in 91 and $85 \%$ yields, respectively (Scheme 17). ${ }^{119}$

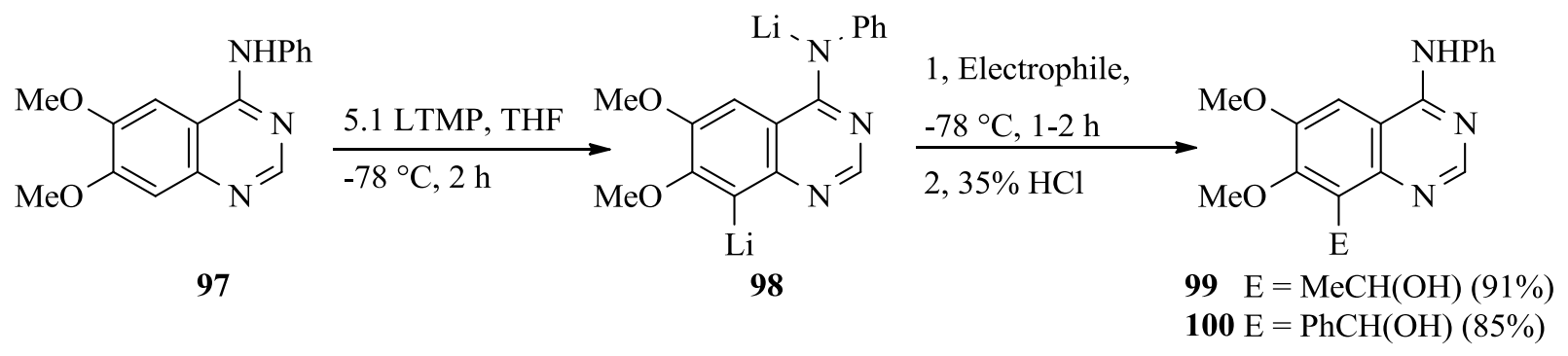

Scheme 17. Directed lithiation and substitution of 97.

Similarly, lithiation of 4-aryl-6,7-dimethoxyquinazolines 101 with LTMP (four molar equivalents) at $-78{ }^{\circ} \mathrm{C}$ gave the corresponding 8-lithio intermediates $\mathbf{1 0 2}$ which on reaction with iodine gave 8-iodoquinazolines 103 and $\mathbf{1 0 4}$ in 66 and 84\% yields, respectively (Scheme 18). ${ }^{122}$

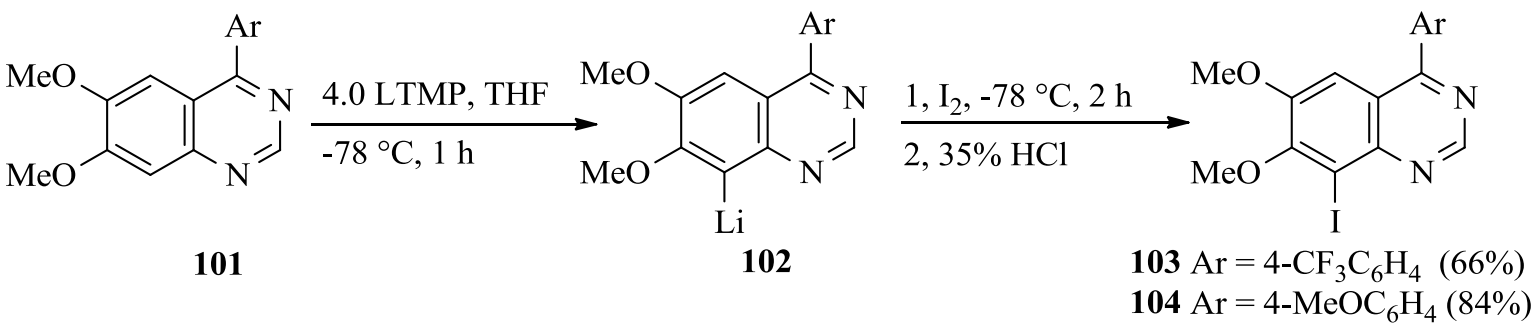

Scheme 18. Directed lithiation of $\mathbf{1 0 1}$ followed by reactions with iodine. 
Lithiation of 4-methoxyquinazoline 105 with four molar equivalents of LTMP in THF at $78 \mathrm{C}$ for $30 \mathrm{~min}$ followed by reaction with acetaldehyde gave a mixture of alcohols $\mathbf{1 0 6}$ and $\mathbf{1 0 7}$ in 66 and 35\% yields, respectively (Scheme 19). ${ }^{121}$ Clearly, a competitive lithiation took place at C-2 and C-8.<smiles>[M]Oc1ncnc2ccccc12</smiles>
105

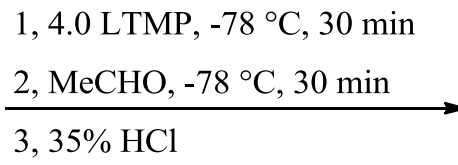
$3,35 \% \mathrm{HCl}$<smiles>COc1nc(C(C)O)nc2ccccc12</smiles>

$106(66 \%)$<smiles>COc1ncnc2c(C(C)O)cccc12</smiles>

$107(35 \%)$

Scheme 19. Lithiation of $\mathbf{1 0 5}$ followed by reaction with acetaldehyde.

Lithiation of 4-methoxy-2-phenylquinazoline 108 with excess LTMP (two molar equivalents) in THF at $0{ }^{\circ} \mathrm{C}$ was regioselective at $\mathrm{C}-8$ to give the 8 -lithium intermediate 109 (Scheme 20). ${ }^{121}$ Reactions of $\mathbf{1 0 9}$ with acetaldehyde and trimethylsilyl chloride gave the corresponding 8-substituted derivatives 110 and 111 in 56 and 94\% yields, respectively. ${ }^{121}$

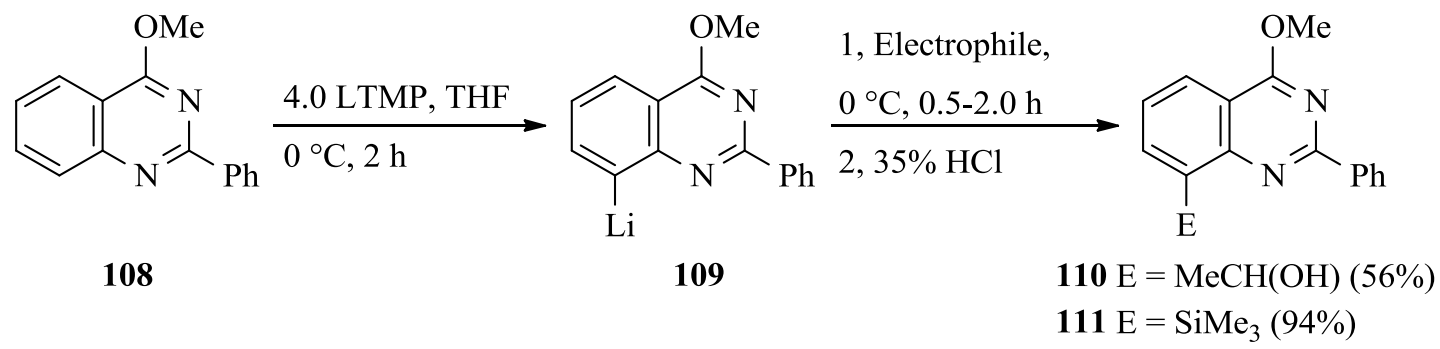

Scheme 20. Lithiation of $\mathbf{1 0 8}$ followed by reactions with electrophiles.

Similarly, lithiation of 4,6-dimethoxyquinazoline 112 with 2.2 molar equivalents of LTMP in THF at $-78{ }^{\circ} \mathrm{C}$ gave 8 -lithium intermediate 113 that reacted with acetaldehyde to give alcohol 114 in $54 \%$ yield (Scheme 21). ${ }^{121}$

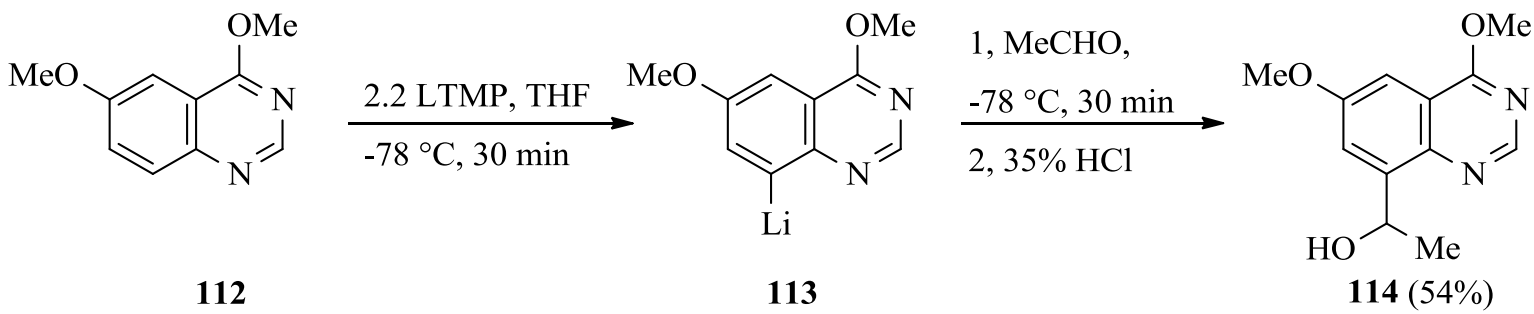

Scheme 21. Lithiation of $\mathbf{1 1 2}$ followed by reaction with acetaldehyde. 


\section{Lateral Lithiation of 2-n-Alkylquinazoline Derivatives}

Lateral lithiation of various 2 - $n$-alkyl-3H-quinazolin-4-ones containing various groups at the 3-position, such as acylamino, methylamino, amino, aryl and a hydrogen, have been attempted by the use of BuLi or LDA at low temperature. The lithiation took place at the benzylic position of the $n$-alkyl group. These procedures provide efficient syntheses of more complex 2-substituted derivatives in high yields. Similar procedures have been applied to 3 -unsubstituted 2- $n$-alkyl-3Hquinazolin-4-ones, their thiones and 4-substituted quinazolines.

\subsection{Lateral lithiation of 3-acylamino-2-n-alkyl-3H-quinazolin-4-ones}

Lateral lithiation of various 3-acylamino-2- $n$-alkyl-3H-quinazolin-4-ones 115 was achieved by the use of 2.2 molar equivalents of $n$-BuLi (for $\mathrm{R}^{1}=\mathrm{Me}$ ) or LDA (for $\mathrm{R}^{1}=\mathrm{Et}$ and $n$-Pr) in anhydrous THF at $-78^{\circ} \mathrm{C}$ (Scheme 22). ${ }^{115,127,128}$ Lithiation was regioselective at the carbon $\alpha$ to the 2-position of the $3 \mathrm{H}$-quinazolin-4-one moiety. Addition of the first equivalent of the alkyllithium produced the monolithium reagents 116, which were converted into the dilithium reagents 117 on addition of the second equivalent of alkyllithium (Scheme 22). ${ }^{115,127,128}$

Reactions of 117 with a variety of electrophiles afforded the corresponding 2-substituted $3 \mathrm{H}$ quinazolin-4-ones 20-23 and 118-163 (Scheme 22) in high yields (Tables 7-10). On the other hand, lithiation of 2-(1-methylethyl)-3H-quinazolin-4-ones 21 and 23 and 3-diacylamino-2-nalkyl-3H-quinazolin-4-ones were not successful under similar reaction conditions. ${ }^{115}$

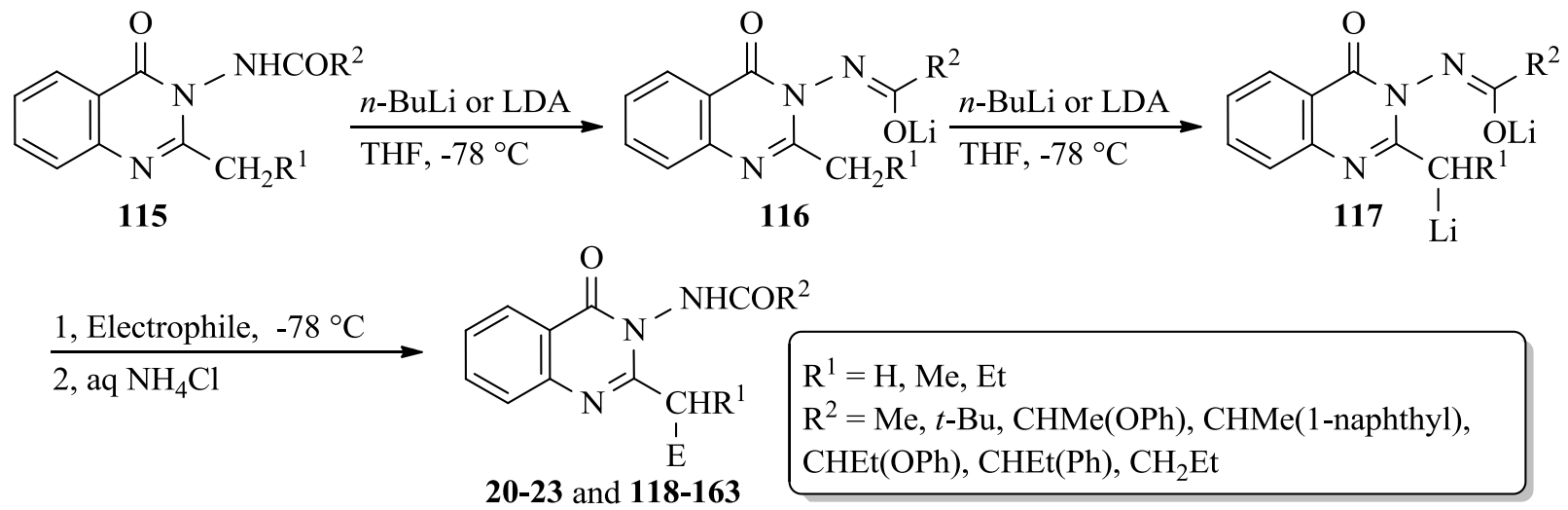

Scheme 22. Lateral lithiation and substitution of $\mathbf{1 1 5 .}$

The NMR spectra for compounds reported in Table 7 except for cases where the electrophile was $\mathrm{D}_{2} \mathrm{O}$ (i.e. products 122 and 127) showed that the two hydrogen atoms of the $\mathrm{CH}_{2}$ group at the 2-position occurred as independent, coupled signals, suggesting they are diastereotopic due to the barrier to rotation around the $N-N$ bond. The crystal structure of compound 118 showed that the plane of the aromatic ring is orthogonal to the plane of the ${ }^{t} \mathrm{BuCONH}$ group. This renders the $N-N$ bond as a chiral axis. Orthogonal conformations are known to be significantly more stable than their co-planar counterparts for $N, N^{\prime}$-diacylhydrazines, which has resulted in measured 
barriers to rotation about the $N-N$ bond. ${ }^{129,130}$ Barriers to rotation have been reported for di- and tetraacylhydrazines, where both nitrogen atoms are of amide type, ${ }^{131-134}$ hydrazines, ${ }^{135}$ triazines ${ }^{136}$ and tetrazines. ${ }^{137}$ Also, hindrance to rotation about the $N-N$ bond in 3 -acylamino- and 3-diacylamino-3H-quinazolin-4-ones was found to be as high as for hydrazine derivatives (14.720.6 Kcal mol$\left.{ }^{-1}\right) .{ }^{138,139}$

Table 7. Lithiation and substitution of $\mathbf{1 1 5}\left(\mathrm{R}^{1}=\mathrm{H} ; \mathrm{R}^{2}=\mathrm{Me}, t\right.$-Bu) using $n$-BuLi as the lithium reagent according to Scheme $22^{127}$

\begin{tabular}{|c|c|c|c|c|}
\hline Product & $\mathrm{R}^{2}$ & Electrophile & $\mathrm{E}$ & Yield $(\%)^{\mathrm{a}, \mathrm{b}}$ \\
\hline 20 & $t$-Bu & MeI & $\mathrm{Me}$ & 89 \\
\hline 118 & $t$-Bu & $\mathrm{Ph}_{2} \mathrm{CO}$ & $\mathrm{Ph}_{2} \mathrm{C}(\mathrm{OH})$ & 83 \\
\hline 119 & $t$-Bu & $\mathrm{PhCOMe}$ & $\mathrm{PhC}(\mathrm{OH})(\mathrm{Me})$ & 81 \\
\hline 120 & $t$-Bu & $\left(\mathrm{CH}_{2}\right)_{5} \mathrm{CO}$ & $\left(\mathrm{CH}_{2}\right)_{5} \mathrm{C}(\mathrm{OH})$ & 80 \\
\hline 121 & $t$-Bu & $\mathrm{PhNCO}$ & PhNHCO & 84 \\
\hline 122 & $t$-Bu & $\mathrm{D}_{2} \mathrm{O}$ & D & 88 \\
\hline 22 & $\mathrm{Me}$ & MeI & $\mathrm{Me}$ & 75 \\
\hline 123 & $\mathrm{Me}$ & $\mathrm{Ph}_{2} \mathrm{CO}$ & $\mathrm{Ph}_{2} \mathrm{C}(\mathrm{OH})$ & 80 \\
\hline 124 & $\mathrm{Me}$ & $\mathrm{PhCOMe}$ & $\mathrm{PhC}(\mathrm{OH})(\mathrm{Me})$ & 84 \\
\hline 125 & $\mathrm{Me}$ & $\left(\mathrm{CH}_{2}\right)_{5} \mathrm{CO}$ & $\left(\mathrm{CH}_{2}\right)_{5} \mathrm{C}(\mathrm{OH})$ & 79 \\
\hline 126 & $\mathrm{Me}$ & PhNCO & PhNHCO & 83 \\
\hline 127 & $\mathrm{Me}$ & $\mathrm{D}_{2} \mathrm{O}$ & $\mathrm{D}$ & 74 \\
\hline
\end{tabular}

${ }^{\mathrm{a}}$ Yield of isolated product after crystallization from ethyl acetate.

Table 8. Lithiation and substitution of $115\left(\mathrm{R}^{1}=\mathrm{Me}, \mathrm{Et} ; \mathrm{R}^{2}=t\right.$-Bu) using LDA as the lithium reagent according to Scheme $22^{115}$

\begin{tabular}{ccccc}
\hline Product & $\mathrm{R}^{1}$ & Electrophile & $\mathrm{E}$ & ${\text { Yield }(\%)^{\mathrm{a}}}^{\mathrm{a}}$ \\
$\mathbf{2 1}$ & $\mathrm{Me}$ & $\mathrm{MeI}$ & $\mathrm{Me}$ & 92 \\
$\mathbf{1 2 8}$ & $\mathrm{Me}$ & $\mathrm{Ph}_{2} \mathrm{CO}$ & $\mathrm{Ph}_{2} \mathrm{C}(\mathrm{OH})$ & 90 \\
$\mathbf{1 2 9}$ & $\mathrm{Me}$ & $\mathrm{PhCOMe}$ & $\mathrm{PhC}(\mathrm{OH})(\mathrm{Me})$ & 81 \\
$\mathbf{1 3 0}$ & $\mathrm{Me}$ & $\left(\mathrm{CH}_{2}\right)_{5} \mathrm{CO}$ & $\left(\mathrm{CH}_{2}\right)_{5} \mathrm{C}(\mathrm{OH})$ & 82 \\
$\mathbf{1 3 1}$ & $\mathrm{Me}$ & $\left(\mathrm{CH}_{2}\right)_{4} \mathrm{CO}$ & $\left(\mathrm{CH}_{2}\right)_{4} \mathrm{C}(\mathrm{OH})$ & 84 \\
$\mathbf{1 3 2}$ & $\mathrm{Me}$ & $\mathrm{I}_{2}$ & $\mathrm{I}$ & 70 \\
$\mathbf{1 3 3}$ & $\mathrm{Me}$ & $\mathrm{D}_{2} \mathrm{O}$ & $\mathrm{D}$ & 88 \\
$\mathbf{1 3 4}$ & $\mathrm{Et}$ & $\mathrm{MeI}$ & $\mathrm{Me}$ & 90 \\
$\mathbf{1 3 5}$ & $\mathrm{Et}$ & $\mathrm{Ph}_{2} \mathrm{CO}$ & $\mathrm{Ph}_{2} \mathrm{C}(\mathrm{OH})$ & 92 \\
$\mathbf{1 3 6}$ & $\mathrm{Et}$ & $\left(\mathrm{CH}_{2}\right)_{5} \mathrm{CO}$ & $\left(\mathrm{CH}_{2}\right)_{5} \mathrm{C}(\mathrm{OH})$ & 88 \\
${ }^{\mathrm{a}}$ Yield of isolated product after crystallization from ethyl acetate.
\end{tabular}


Table 9. Lithiation and substitution of $\mathbf{1 1 5}\left(\mathrm{R}^{1}=\mathrm{Me}, \mathrm{Et} ; \mathrm{R}^{2}=\mathrm{Me}\right)$ using LDA as the lithium reagent according to Scheme $22^{115}$

\begin{tabular}{ccccc}
\hline Product & $\mathrm{R}^{1}$ & Electrophile & $\mathrm{E}$ & ${\text { Yield }(\%)^{\mathrm{a}}}^{\mathrm{a}}$ \\
\hline $\mathbf{2 3}$ & $\mathrm{Me}$ & $\mathrm{MeI}$ & $\mathrm{Me}$ & 84 \\
$\mathbf{1 3 7}$ & $\mathrm{Me}$ & $\mathrm{Ph}_{2} \mathrm{CO}$ & $\mathrm{Ph}_{2} \mathrm{C}(\mathrm{OH})$ & $80^{\mathrm{b}}$ \\
$\mathbf{1 3 8}$ & $\mathrm{Me}$ & $\mathrm{PhCOMe}$ & $\mathrm{PhC}(\mathrm{OH})(\mathrm{Me})$ & 77 \\
$\mathbf{1 3 9}$ & $\mathrm{Me}$ & $\left(\mathrm{CH}_{2}\right)_{5} \mathrm{CO}$ & $\left(\mathrm{CH}_{2}\right)_{5} \mathrm{C}(\mathrm{OH})$ & $82^{\mathrm{c}}$ \\
$\mathbf{1 4 0}$ & $\mathrm{Me}$ & $\left(\mathrm{CH}_{2}\right)_{4} \mathrm{CO}$ & $\left(\mathrm{CH}_{2}\right)_{4} \mathrm{C}(\mathrm{OH})$ & 80 \\
$\mathbf{1 4 1}$ & $\mathrm{Me}$ & $\mathrm{I}_{2}$ & $\mathrm{I}$ & 70 \\
$\mathbf{1 4 2}$ & $\mathrm{Me}$ & $\mathrm{D}_{2} \mathrm{O}$ & $\mathrm{D}$ & 81 \\
$\mathbf{1 4 3}$ & $\mathrm{Et}$ & $\mathrm{MeI}$ & $\mathrm{Me}$ & 86 \\
$\mathbf{1 4 4}$ & $\mathrm{Et}$ & $\mathrm{Ph}_{2} \mathrm{CO}$ & $\mathrm{Ph}_{2} \mathrm{C}(\mathrm{OH})$ & 87 \\
$\mathbf{1 4 5}$ & $\mathrm{Et}$ & $\left(\mathrm{CH}_{2}\right)_{5} \mathrm{CO}$ & $\left(\mathrm{CH}_{2}\right)_{5} \mathrm{C}(\mathrm{OH})$ & $85^{\mathrm{d}}$ \\
\hline
\end{tabular}

' Yield of isolated product after crystallization from ethyl acetate.

${ }^{\text {b-d }}$ Compounds 146-148 (Figure 4) were obtained as by products in 3-5\% yields. Such compounds were produced due to lithiation and substitution on the methyl group of the acetylamino unit at the 3-position.

It was possible to remove the acyl group from products reported in Tables 7-9 under hot basic or acidic conditions to produce 2 - $n$-alkyl-3-amino-3H-quinazolin-4-ones. ${ }^{15,127}$ For example, hydrolysis of compounds $\mathbf{2 0 - 2 3}$ with hydrochloric acid or aqueous sodium hydroxide in methanol under reflux removed the acyl group to give the corresponding 3-amino-derivatives in 75\% yields. ${ }^{115}$ However, such forcing conditions for removal of the acylamino group were not always appropriate for some of the more complicated substituents at the 2-position.<smiles>CC(C(=O)O)c1nc2ccccc2c(=O)n1NC(=O)CC(=O)OCc1ccccc1</smiles>

$146(3 \%)$

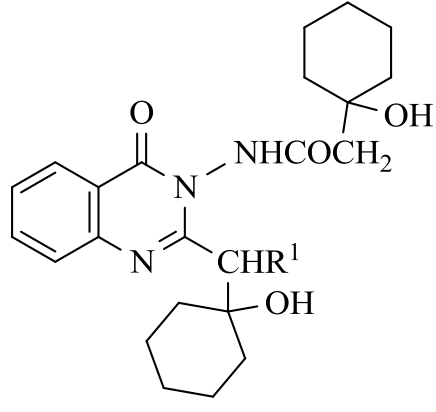

$147 \mathrm{R}^{1}=\mathrm{Me}(4 \%)$

$148 \mathrm{R}^{1}=$ Et $(5 \%)$

Figure 4. Structures of compounds 146-148. 
Table 10. Lithiation and substitution of $115\left(\mathrm{R}^{1}=\mathrm{Me}, \mathrm{Et} ; \mathrm{R}^{2}=\mathrm{CHMe}(\mathrm{OPh})\right.$, $\mathrm{CHMe}\left(1-\right.$ naphthyl), $\mathrm{CHEt}(\mathrm{OPh}), \mathrm{CHEt}(\mathrm{Ph})$ using LDA according to Scheme $22^{128}$

\begin{tabular}{|c|c|c|c|c|c|}
\hline Product & $\mathrm{R}^{1}$ & $\mathrm{R}^{2}$ & Electrophile & $\mathrm{E}$ & Yield $(\%)^{\mathrm{a}}$ \\
\hline 149 & $\mathrm{Me}$ & $\mathrm{CHMe}(\mathrm{OPh})$ & $\mathrm{Ph}_{2} \mathrm{CO}$ & $\mathrm{Ph}_{2} \mathrm{C}(\mathrm{OH})$ & 80 \\
\hline 150 & $\mathrm{Me}$ & $\mathrm{CHMe}(\mathrm{OPh})$ & PhCOMe & $\mathrm{PhC}(\mathrm{OH})(\mathrm{Me})$ & 78 \\
\hline 151 & $\mathrm{Me}$ & $\mathrm{CHMe}(\mathrm{OPh})$ & $\mathrm{PhCHO}$ & $\mathrm{PhCH}(\mathrm{OH})$ & 82 \\
\hline 152 & $\mathrm{Me}$ & CHMe(1-naphthyl) & $\mathrm{Ph}_{2} \mathrm{CO}$ & $\mathrm{Ph}_{2} \mathrm{C}(\mathrm{OH})$ & 79 \\
\hline 153 & $\mathrm{Me}$ & $\mathrm{CHEt}(\mathrm{OPh})$ & $\mathrm{Ph}_{2} \mathrm{CO}$ & $\mathrm{Ph}_{2} \mathrm{C}(\mathrm{OH})$ & 76 \\
\hline 154 & $\mathrm{Me}$ & $\mathrm{CHEt}(\mathrm{OPh})$ & PhCOMe & $\mathrm{PhC}(\mathrm{OH})(\mathrm{Me})$ & 79 \\
\hline 155 & $\mathrm{Me}$ & $\mathrm{CHEt}(\mathrm{OPh})$ & $\mathrm{PhCHO}$ & $\mathrm{PhCH}(\mathrm{OH})$ & 80 \\
\hline 156 & $\mathrm{Me}$ & $\mathrm{CHEt}(\mathrm{Ph})$ & $\mathrm{Ph}_{2} \mathrm{CO}$ & $\mathrm{Ph}_{2} \mathrm{C}(\mathrm{OH})$ & 77 \\
\hline 157 & $\mathrm{Me}$ & $\mathrm{CHEt}(\mathrm{Ph})$ & $\mathrm{Et}(\mathrm{Me}) \mathrm{CO}$ & $\mathrm{EtC}(\mathrm{OH}) \mathrm{Me}$ & 75 \\
\hline 158 & $\mathrm{Et}$ & $\mathrm{CHMe}(\mathrm{OPh})$ & $\mathrm{Ph}_{2} \mathrm{CO}$ & $\mathrm{Ph}_{2} \mathrm{C}(\mathrm{OH})$ & 88 \\
\hline 159 & $\mathrm{Et}$ & $\mathrm{CHMe}(\mathrm{OPh})$ & PhCOMe & $\mathrm{PhC}(\mathrm{OH})(\mathrm{Me})$ & 80 \\
\hline 160 & Et & $\mathrm{CHMe}(\mathrm{OPh})$ & $\mathrm{PhCHO}$ & $\mathrm{PhCH}(\mathrm{OH})$ & 76 \\
\hline 161 & $\mathrm{Et}$ & $\mathrm{CHEt}(\mathrm{OPh})$ & $\mathrm{Ph}_{2} \mathrm{CO}$ & $\mathrm{Ph}_{2} \mathrm{C}(\mathrm{OH})$ & 90 \\
\hline 162 & $\mathrm{Et}$ & $\mathrm{CHEt}(\mathrm{OPh})$ & PhCOMe & $\mathrm{PhC}(\mathrm{OH})(\mathrm{Me})$ & 78 \\
\hline 163 & Et & $\mathrm{CHEt}(\mathrm{OPh})$ & $\mathrm{PhCHO}$ & $\mathrm{PhCH}(\mathrm{OH})$ & 80 \\
\hline
\end{tabular}

${ }^{\mathrm{a}}$ Yield of isolated product after crystallization from ethyl acetate.

The NMR spectra of products 149-163 (Table 10) showed the expected diastereotopic feature for all the $\mathrm{CH}_{2}$ groups and provided evidence for long-range asymmetric induction at the newly created asymmetric centre(s). This opens up possibilities for novel synthetic approaches to certain types of chiral compounds. ${ }^{128}$

\subsection{Lateral lithiation of $2-\boldsymbol{n}$-alkyl-3-amino-3H-quinazolin-4-ones}

Lateral lithiation of 2-n-alkyl-3-amino- and 2-n-alkyl-3-methylamino-3H-quinazolin-4-ones 164 took place by the use 2.2 molar equivalents of alkyllithium (Scheme $23 ; n$-BuLi for $\mathrm{R}^{1}=\mathrm{H}$ and LDA for $\mathrm{R}^{1}=\mathrm{Me}, \mathrm{Et}$ ) at $-78^{\circ} \mathrm{C}$ in THF to give deep red solutions of dilithium reagents $\mathbf{1 6 5}{ }^{140}$ Reactions of the dilithium reagents 165 with various electrophiles at -78 or $0{ }^{\circ} \mathrm{C}$ in $\mathrm{THF}$ gave the corresponding 2-substituted derivatives 166-194 in high yields (Tables 11 and 12). ${ }^{140}$

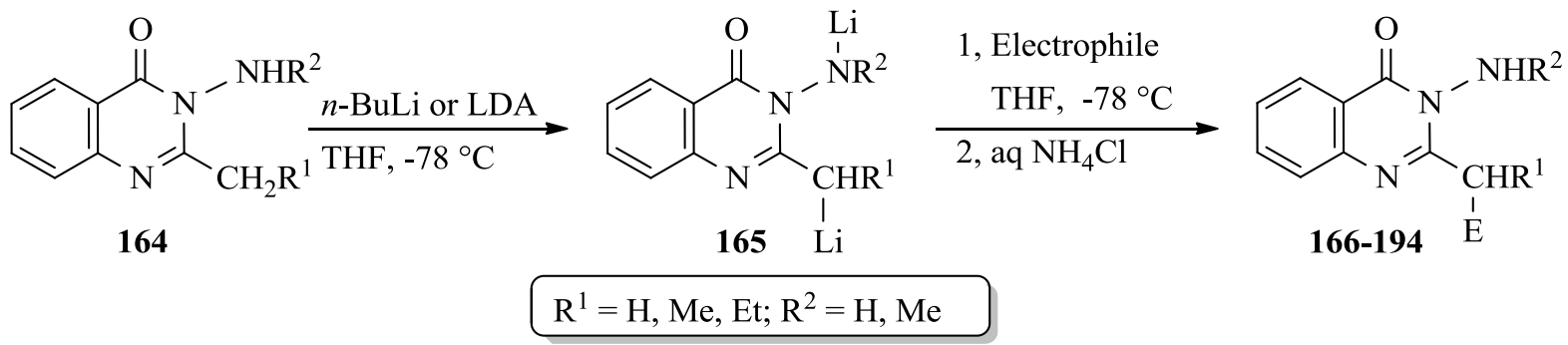

Scheme 23. Lateral lithiation and substitution of 164. 
Table 11. Lithiation and substitution of $\mathbf{1 6 4}\left(\mathrm{R}^{1}=\mathrm{H}, \mathrm{Me}\right.$, Et; $\left.\mathrm{R}^{2}=\mathrm{H}\right)$ using $n$-BuLi or LDA according to Scheme $23^{140}$

\begin{tabular}{|c|c|c|c|c|}
\hline Product & $\mathrm{R}^{1}$ & Electrophile & E & Yield $(\%)$ \\
\hline 166 & $\mathrm{H}$ & $\mathrm{Ph}_{2} \mathrm{CO}$ & $\mathrm{Ph}_{2} \mathrm{C}(\mathrm{OH})$ & 86 \\
\hline 167 & $\mathrm{H}$ & $\mathrm{PhCOMe}$ & $\mathrm{PhC}(\mathrm{OH})(\mathrm{Me})$ & 86 \\
\hline 168 & $\mathrm{H}$ & $\left(\mathrm{CH}_{2}\right)_{5} \mathrm{CO}$ & $\left(\mathrm{CH}_{2}\right)_{5} \mathrm{C}(\mathrm{OH})$ & 84 \\
\hline 169 & $\mathrm{H}$ & $\left(\mathrm{CH}_{2}\right)_{4} \mathrm{CO}$ & $\left(\mathrm{CH}_{2}\right)_{4} \mathrm{C}(\mathrm{OH})$ & 89 \\
\hline 170 & $\mathrm{H}$ & $\mathrm{PhCHO}$ & $\mathrm{PhCH}(\mathrm{OH})$ & 77 \\
\hline 171 & $\mathrm{H}$ & {$\left[{ }^{i} \mathrm{Pr}_{2} \mathrm{NC}(\mathrm{S}) \mathrm{S}\right]_{2}$} & ${ }^{i} \operatorname{Pr}_{2} \mathrm{NC}(\mathrm{S}) \mathrm{S}$ & 75 \\
\hline 172 & $\mathrm{H}$ & $\mathrm{D}_{2} \mathrm{O}$ & D & 88 \\
\hline 173 & $\mathrm{Me}$ & $\mathrm{Ph}_{2} \mathrm{CO}$ & $\mathrm{Ph}_{2} \mathrm{C}(\mathrm{OH})$ & 84 \\
\hline 174 & $\mathrm{Me}$ & $\mathrm{PhCOMe}$ & $\mathrm{PhC}(\mathrm{OH})(\mathrm{Me})$ & 80 \\
\hline 175 & $\mathrm{Me}$ & EtCOMe & $\mathrm{EtC}(\mathrm{OH}) \mathrm{Me}$ & 88 \\
\hline 176 & $\mathrm{Me}$ & ${ }^{n} \mathrm{BuCOMe}$ & ${ }^{n} \mathrm{BuC}(\mathrm{OH}) \mathrm{Me}$ & 71 \\
\hline 177 & $\mathrm{Me}$ & ${ }^{n} \mathrm{BuCOEt}$ & ${ }^{n} \mathrm{BuC}(\mathrm{OH}) \mathrm{Et}$ & 83 \\
\hline 178 & $\mathrm{Me}$ & $\left(\mathrm{CH}_{2}\right)_{5} \mathrm{CO}$ & $\left(\mathrm{CH}_{2}\right)_{5} \mathrm{C}(\mathrm{OH})$ & 90 \\
\hline 179 & $\mathrm{Me}$ & $\left(\mathrm{CH}_{2}\right)_{4} \mathrm{CO}$ & $\left(\mathrm{CH}_{2}\right)_{4} \mathrm{C}(\mathrm{OH})$ & 90 \\
\hline 180 & $\mathrm{Me}$ & PhCHO & $\mathrm{PhCH}(\mathrm{OH})$ & 80 \\
\hline 181 & $\mathrm{Me}$ & $\mathrm{D}_{2} \mathrm{O}$ & D & 92 \\
\hline 182 & Et & $\mathrm{Ph}_{2} \mathrm{CO}$ & $\mathrm{Ph}_{2} \mathrm{C}(\mathrm{OH})$ & 90 \\
\hline 183 & $\mathrm{Et}$ & $\mathrm{PhCOMe}$ & $\mathrm{PhC}(\mathrm{OH})(\mathrm{Me})$ & 87 \\
\hline 184 & $\mathrm{Et}$ & EtCOMe & $\mathrm{EtC}(\mathrm{OH}) \mathrm{Me}$ & 92 \\
\hline
\end{tabular}

a Yield of isolated product after crystallization, usually from diethyl ether.

Table 12. Lithiation and substitution of $\mathbf{1 6 4}\left(\mathrm{R}^{1}=\mathrm{H}, \mathrm{Me}, \mathrm{Et} ; \mathrm{R}^{2}=\mathrm{Me}\right)$ using $n$-BuLi or LDA according to Scheme $23^{140}$

\begin{tabular}{ccccc}
\hline Product & $\mathrm{R}^{1}$ & Electrophile & $\mathrm{E}$ & ${\text { Yield }(\%)^{\mathrm{a}}}^{\mathrm{a}}$ \\
\hline $\mathbf{1 8 5}$ & $\mathrm{H}$ & $\mathrm{Ph}_{2} \mathrm{CO}$ & $\mathrm{Ph}_{2} \mathrm{C}(\mathrm{OH})$ & 83 \\
$\mathbf{1 8 6}$ & $\mathrm{H}$ & $\mathrm{EtCOMe}$ & $\mathrm{EtC}(\mathrm{OH}) \mathrm{Me}$ & 84 \\
$\mathbf{1 8 7}$ & $\mathrm{H}$ & $\mathrm{PhCHO}$ & $\mathrm{PhCH}(\mathrm{OH})$ & 70 \\
$\mathbf{1 8 8}$ & $\mathrm{H}$ & $\mathrm{PhNCO}$ & $\mathrm{PhNHCO}$ & 72 \\
$\mathbf{1 8 9}$ & $\mathrm{H}$ & $\mathrm{D}_{2} \mathrm{O}$ & $\mathrm{D}$ & 90 \\
$\mathbf{1 9 0}$ & $\mathrm{Me}$ & $\mathrm{Ph}_{2} \mathrm{CO}$ & $\mathrm{Ph}_{2} \mathrm{C}(\mathrm{OH})$ & 82 \\
$\mathbf{1 9 1}$ & $\mathrm{Me}$ & $\left(\mathrm{CH}_{2}\right)_{4} \mathrm{CO}$ & $\left(\mathrm{CH}_{2}\right)_{4} \mathrm{C}(\mathrm{OH})$ & 80 \\
$\mathbf{1 9 2}$ & $\mathrm{Me}$ & $\mathrm{PhNCO}_{10}$ & $\mathrm{PhNHCO}$ & 66 \\
$\mathbf{1 9 3}$ & $\mathrm{Me}$ & $\mathrm{D}_{2} \mathrm{O}$ & $\mathrm{D}$ & 82 \\
$\mathbf{1 9 4}$ & $\mathrm{Et}$ & $\mathrm{Ph}_{2} \mathrm{CO}$ & $\mathrm{Ph}_{2} \mathrm{C}(\mathrm{OH})$ & 80 \\
\hline
\end{tabular}

a Yield of isolated product after crystallization, usually from diethyl ether. 
The ambient temperature ${ }^{1} \mathrm{H}$ NMR spectra of compounds 182-184 (Table 11) and 194 (Table 12) showed that the two hydrogens of the $\mathrm{CH}_{2}$ group adjacent to the newly created asymmetric center are diastereotopic, indicating a significant barrier to rotation around the $N-N$ bond even at room temperature. ${ }^{140}$

Clearly the process represented in Scheme 23 was general, high yielding and accommodated various complex substituents at the $\alpha$-carbon at the 2-position.

Lateral lithiation of $\mathbf{1 6 4}$ with a lithium reagent (Scheme $24 ; n$-BuLi for $\mathrm{R}^{1}=\mathrm{H}$ or LDA for $\mathrm{R}^{1}=\mathrm{Me}, \mathrm{Et}$ ) at $-78{ }^{\circ} \mathrm{C}$ followed by reactions with two molar equivalents of iodomethane or phenyl isocycanate at -78 or $0{ }^{\circ} \mathrm{C}$ gave the corresponding disubstituted derivatives 195-201 in high yields (Table 13). ${ }^{140}$ Clearly, substitution at both the $\alpha$-carbon at the 2 -position and the nitrogen attached to the 3-position had taken place.

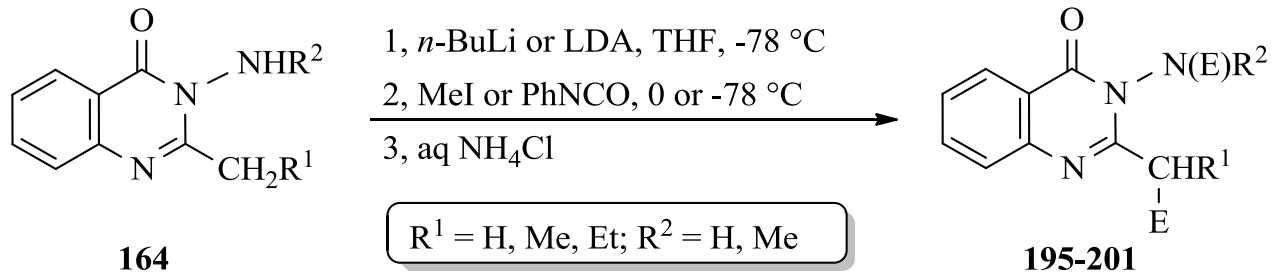

Scheme 24. Lateral lithiation and double substitution of 164.

Table 13. Lithiation and double substitution of $\mathbf{1 6 4}$ according to Scheme $24^{140}$

\begin{tabular}{llllll}
\hline Product & $\mathrm{R}^{1}$ & $\mathrm{R}^{2}$ & Electrophile & $\mathrm{E}$ & ${\text { Yield }(\%)^{\mathrm{a}}}^{(19}$ \\
\hline $\mathbf{1 9 5}$ & $\mathrm{H}$ & $\mathrm{H}$ & $\mathrm{MeI}$ & $\mathrm{Me}$ & 89 \\
$\mathbf{1 9 6}$ & $\mathrm{H}$ & $\mathrm{H}$ & $\mathrm{PhNCO}$ & $\mathrm{PhNCO}$ & 75 \\
$\mathbf{1 9 7}$ & $\mathrm{H}$ & $\mathrm{Me}$ & $\mathrm{MeI}$ & $\mathrm{Me}$ & 80 \\
$\mathbf{1 9 8}$ & $\mathrm{Me}$ & $\mathrm{H}$ & $\mathrm{MeI}$ & $\mathrm{Me}$ & 86 \\
$\mathbf{1 9 9}$ & $\mathrm{Me}$ & $\mathrm{Me}$ & $\mathrm{MeI}$ & $\mathrm{Me}$ & 88 \\
$\mathbf{2 0 0}$ & $\mathrm{Me}$ & $\mathrm{H}$ & $\mathrm{PhNCO}$ & $\mathrm{PhNCO}$ & 70 \\
$\mathbf{2 0 1}$ & $\mathrm{Et}$ & $\mathrm{Me}$ & $\mathrm{MeI}$ & $\mathrm{Me}$ & 79 \\
\hline
\end{tabular}

Y Yield of isolated product after crystallization, usually from diethyl ether.

Reaction of the dilithium reagent obtained in situ from lithiation of 3-amino-2-ethyl-3Hquinazolin-4-one 164a with tetraisopropylthiuram disulfide (TITD) gave compound 202 in $71 \%$ yield, in which deamination had taken place (Scheme 25). ${ }^{140}$ Lithiation of 3-dimethylamino-2ethyl-3H-quinazolin-4-one under similar reaction conditions was not successful. ${ }^{140}$

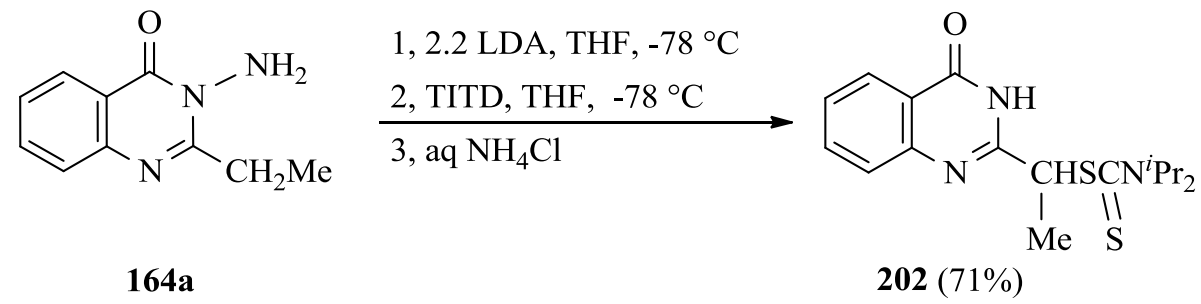

Scheme 25. Synthesis of 2-[1-(diisopropyldithiocarbamoyl)ethyl]-3H-quinazolin-4-one 202. 


\subsection{Lateral lithiation of 3-substituted 2-methyl-3H-quinazolin-4-ones}

Lithiation of 3-substituted 2-methyl-3H-quinazolin-4-ones 203 with LDA in THF-hexane mixture at $0{ }^{\circ} \mathrm{C}$ gave the corresponding lithium intermediates 204 (Scheme 26) as deep red solutions. ${ }^{141}$ Reactions of $\mathbf{2 0 4}$ with various electrophiles afforded the corresponding 2,3-disubstituted derivatives $\mathbf{2 0 5 - 2 1 5}$ (Scheme 26) in 22-92\% yields (Table 14). ${ }^{141}$

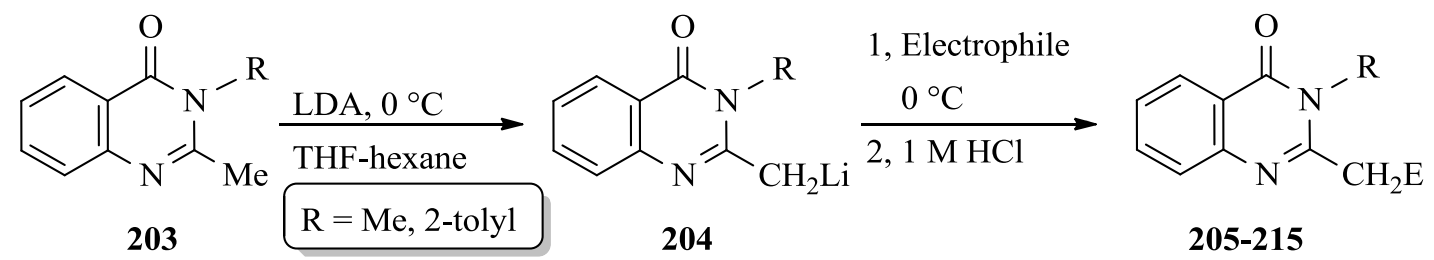

Scheme 26. Lateral lithiation and substitution of 203.

Table 14. Lithiation and substitution of $\mathbf{2 0 3}$ according to Scheme $26^{141}$

\begin{tabular}{|c|c|c|c|c|}
\hline Product & $\mathrm{R}$ & Electrophile & $\mathrm{E}$ & Yield $(\%)^{\mathrm{a}}$ \\
\hline 205 & $\mathrm{Me}$ & $\mathrm{PhCHO}$ & $\mathrm{PhCH}(\mathrm{OH})$ & 73 \\
\hline 206 & $\mathrm{Me}$ & $\mathrm{Ph}_{2} \mathrm{CO}$ & $\mathrm{Ph}_{2} \mathrm{C}(\mathrm{OH})$ & 69 \\
\hline 207 & $\mathrm{Me}$ & $\mathrm{Me}_{2} \mathrm{CO}$ & $\mathrm{Me}_{2} \mathrm{C}(\mathrm{OH})$ & 41 \\
\hline 208 & 2-tolyl & $\mathrm{PhCHO}$ & $\mathrm{PhCH}(\mathrm{OH})$ & $51^{\mathrm{b}}$ \\
\hline 209 & 2-tolyl & $\left(\mathrm{CH}_{2}\right)_{5} \mathrm{CO}$ & $\left(\mathrm{CH}_{2}\right)_{5} \mathrm{C}(\mathrm{OH})$ & $22^{\mathrm{c}}$ \\
\hline 210 & 2-tolyl & $(\mathrm{PhS})_{2}$ & $\mathrm{PhS}$ & $53^{\mathrm{d}}$ \\
\hline 211 & 2-tolyl & MeI & $\mathrm{Me}$ & 53 \\
\hline 212 & 2-tolyl & EtI & $\mathrm{Et}$ & $25^{\mathrm{e}}$ \\
\hline 213 & 2-tolyl & $\mathrm{CH}=\mathrm{CHCH}_{2} \mathrm{Br}$ & $\mathrm{CH}=\mathrm{CHCH}_{2}$ & 60 \\
\hline 214 & 2-tolyl & $\mathrm{PhI}$ & $\mathrm{Ph}$ & $34^{\mathrm{f}, \mathrm{g}}$ \\
\hline 215 & 2-tolyl & $\mathrm{D}_{2} \mathrm{O}$ & $\mathrm{D}$ & 92 \\
\hline
\end{tabular}

${ }^{\text {a }}$ Yield of isolated product after crystallization or column chromatography.

${ }^{\mathrm{b}} \mathrm{A}$ traces of 2-styryl derivative was obtained as a side-product due to dehydration of $\mathbf{2 0 8}$ along with starting material $203(8 \%)$.

${ }^{\mathrm{c}}$ Starting material $203(56 \%)$ was recovered.

d2-(Bis(phenylthio)methyl)-3-(2-tolyl)-3H-quinazolin-4-one 216 (Figure 5) was obtained in 17\% yield as a side-product due to lithiation and substitution of $\mathbf{2 1 0}$ along with $\mathbf{2 0 3}$ (29\%).

e2-(Pentan-3-yl)-3-(2-tolyl)-3H-quinazolin-4-one 217 (Figure 5) was obtained in 5\% yield due to further lithiation and substitution of 212 along with 203 (42\%).

f-Benzhydryl-3-(2-tolyl)-3H-quinazolin-4-one 218 (Figure 5; >1\%) was obtained due to lithiation and substitution of 214 along with 203 (41\%).

${ }^{\mathrm{g}}$ Obtained from the corresponding 2-potassiomethyl derivative. 
<smiles>Cc1ccccc1-n1c(C(c2ccccc2)c2ccccc2)nc2ccccc2c1=O</smiles>

$216(17 \%)$<smiles>CCC(CC)c1nc2ccccc2c(=O)n1-c1ccccc1C</smiles><smiles>Cc1ccccc1-n1c(C(c2ccccc2)c2ccccc2)nc2ccccc2c1=O</smiles>

Figure 5. Structures of compounds 216-218.

Lithiation of $(S)$-3-2-(diphenylphosphino)-6-methylphenyl)-2-methyl-3H-quinazolin-4-one 219 with 1.2 molar equivalents of $n$-BuLi in anhydrous THF at $-78{ }^{\circ} \mathrm{C}$ followed by reaction with picolinaldehyde gave (E)-3-(2-(diphenylphosphino)-6-methylphenyl)-2-(2-(pyridin-2-yl)vinyl)$3 \mathrm{H}$-quinazolin-4-one $\mathbf{2 2 0}$ in $78 \%$ yield (Scheme 27). ${ }^{142}$ Compound $\mathbf{2 2 0}$ was obtained as a results of dehydration of the substituted product initially produced.<smiles>Cc1cccc(-c2ccccc2)c1-n1c(C)nc2ccccc2c1=O</smiles><smiles>CC(C)CC(C)O</smiles><smiles>Cc1cccc(-c2ccccc2)c1-n1c(/C=C/c2ccccn2)nc2ccccc2c1=O</smiles>

Scheme 27. Lateral lithiation, substitution and dehydration of 219.

\subsection{Lateral lithiation of $2-n$-alkyl-3H-quinazolin-4-ones}

Lateral lithiation of various 2- $n$-alkyl-3H-quinazolin-4-ones 221 has been achieved by the use of 2.2 molar equivalents of $n$ - $\mathrm{BuLi}$ (for $\mathrm{R}=\mathrm{H}$ ) or LDA (for $\mathrm{R}=\mathrm{Me}$ and $\mathrm{Et}$ ) in anhydrous THF at 0 or $-78^{\circ} \mathrm{C}$ (Scheme 28). ${ }^{143-145}$ Lithiation was regioselective at the carbon $\alpha$ to the 2-position of the $3 \mathrm{H}$-quinazolin-4-one moiety to give the dilithium reagents 222 (Scheme 28). ${ }^{143-145}$ Reactions of 222 with various electrophiles gave the corresponding 2-substituted derivatives 223-252 (Scheme 28) in good yields (Tables 15 and 16). ${ }^{143-145}$

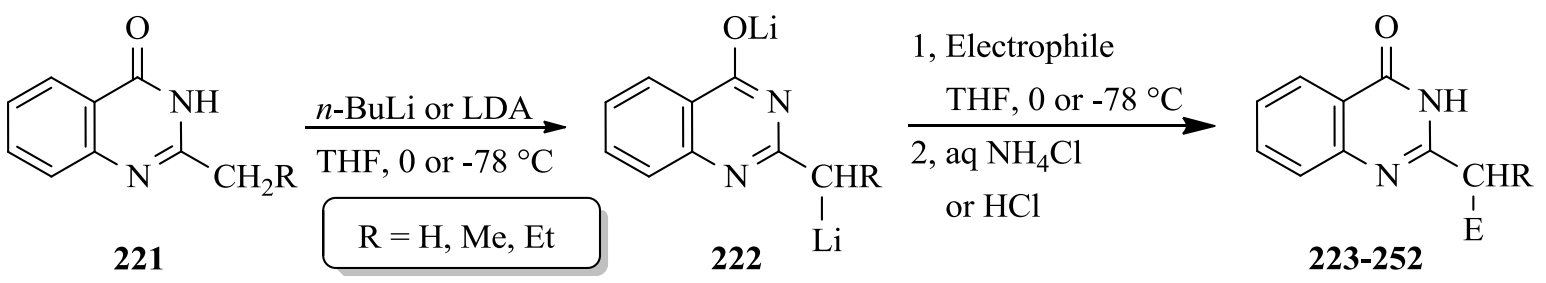

Scheme 28. Lateral lithiation and substitution of 221. 
Table 15. Lithiation and substitution of $221(\mathrm{R}=\mathrm{H})$ according to Scheme $28^{143-145}$

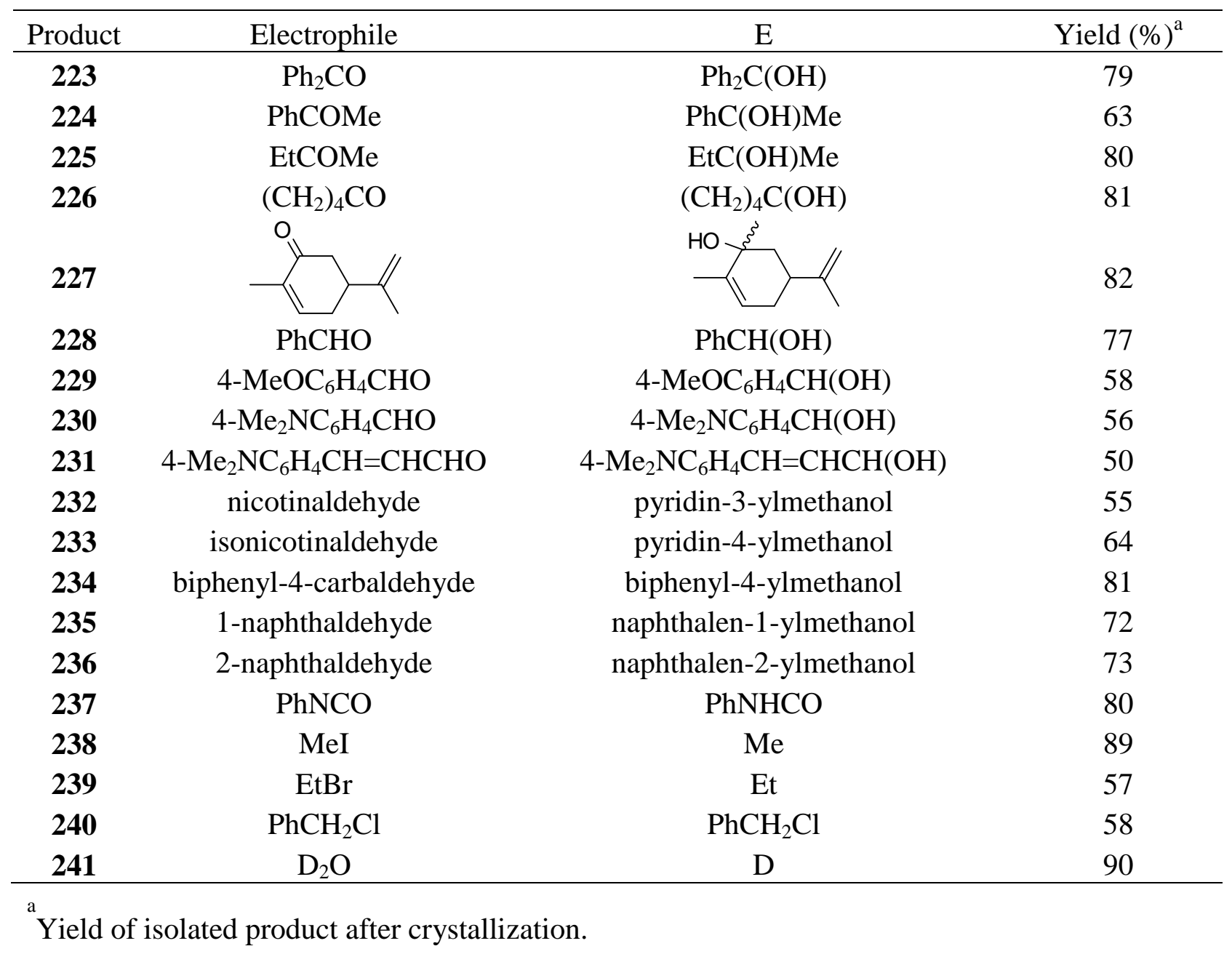

Table 16. Lithiation and substitution of $221(\mathrm{R}=\mathrm{Me}, \mathrm{Et})$ according to Scheme $28^{143}$

\begin{tabular}{ccccc}
\hline Product & $\mathrm{R}$ & Electrophile & $\mathrm{E}$ & ${\text { Yield }(\%)^{\mathrm{a}}}^{\mathrm{a}}$ \\
\hline $\mathbf{2 4 2}$ & $\mathrm{Me}$ & $\mathrm{PhCHO}$ & $\mathrm{PhCH}(\mathrm{OH})$ & 73 \\
$\mathbf{2 4 3}$ & $\mathrm{Me}$ & $\mathrm{Ph}_{2} \mathrm{CO}$ & $\mathrm{Ph}_{2} \mathrm{C}(\mathrm{OH})$ & 78 \\
$\mathbf{2 4 4}$ & $\mathrm{Me}$ & $\mathrm{PhCOMe}$ & $\mathrm{PhC}(\mathrm{OH}) \mathrm{Me}$ & 70 \\
$\mathbf{2 4 5}$ & $\mathrm{Me}$ & $\mathrm{PhNCO}$ & $\mathrm{PhNHCO}$ & 62 \\
$\mathbf{2 4 6}$ & $\mathrm{Me}$ & $\mathrm{MeI}$ & $\mathrm{Me}$ & 82 \\
$\mathbf{2 4 7}$ & $\mathrm{Me}$ & $\mathrm{D}_{2} \mathrm{O}$ & $\mathrm{D}$ & 87 \\
$\mathbf{2 4 8}$ & $\mathrm{Et}$ & $\mathrm{PhCHO}_{2}$ & $\mathrm{PhCH}(\mathrm{OH})$ & 79 \\
$\mathbf{2 4 9}$ & $\mathrm{Et}$ & $\mathrm{Ph}_{2} \mathrm{CO}$ & $\mathrm{Ph}_{2} \mathrm{C}(\mathrm{OH})$ & 88 \\
$\mathbf{2 5 0}$ & $\mathrm{Et}$ & $\left.\mathrm{PhCOMe}^{25}\right)$ & $\mathrm{PhC}(\mathrm{OH}) \mathrm{Me}$ & 77 \\
$\mathbf{2 5 1}$ & $\mathrm{Et}$ & $\mathrm{MeI}$ & $\mathrm{Me}$ & 79 \\
$\mathbf{2 5 2}$ & $\mathrm{Et}$ & $\mathrm{D}_{2} \mathrm{O}$ & $\mathrm{D}$ & 77 \\
\hline
\end{tabular}

Yield of isolated product after crystallization. 
No $N$-substitution was observed even when excess iodomethane ( 3 molar equivalents) was used. The NMR spectra of products 227 (Table 15), 242, 244, 248 and 250 (Table 16) indicated the presence of two diastereoisomers.

Reaction of the dilithium reagent, obtained in situ from lithiation of 2-methyl-3H-quinazolin4-one 221a, with acetonitrile gave 2-(2-iminopropylidene)-1,2-dihydro-3H-quiazolin-4-one 253 in $72 \%$ yield (Scheme 29) instead of the simple 2 -substituted derivative. ${ }^{143}$ The stability of $\mathbf{2 5 3}$ could be due to an intramolecular hydrogen bond.<smiles>Cc1nc2ccccc2c(=O)[nH]1</smiles>

221a

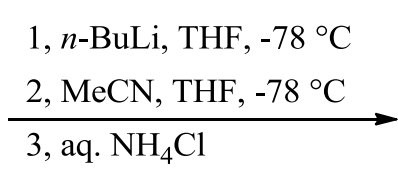

1, $n$-BuLi, THF, $-78^{\circ} \mathrm{C}$

3, aq. $\mathrm{NH}_{4} \mathrm{C}$<smiles>CC(=N)/C=C1\NC(=O)c2ccccc2N1</smiles>

$253(72 \%)$

Scheme 29. Synthesis of 2-(2-iminopropylidene)-1,2-dihydro-3H-quiazolin-4-one 253.

Reaction of the dilithium reagent, obtained in situ from lithiation of 2-ethyl-3H-quinazolin-4one 221b, with iodine took place in different manner. Instead of 2-iodo derivative being formed

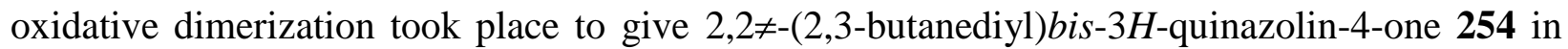
$60 \%$ yield (Scheme 30$)$ after purification. ${ }^{143}$<smiles>CCc1nc2ccccc2c(=O)[nH]1</smiles>

221b
1, $n$-BuLi, THF, $-78^{\circ} \mathrm{C}$

$\underset{3, \text { aq. } \mathrm{NH}_{4} \mathrm{Cl}}{\longrightarrow}$

, aq. $\mathrm{NH}_{4} \mathrm{Cl}$<smiles>CC(C)c1nc2ccccc2c(=O)[nH]1</smiles>

$254(60 \%)$

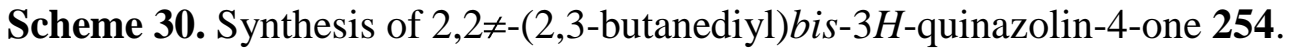

\subsection{Lateral lithiation of 2-n-alkyl-3H-quinazolin-4-thiones}

Lateral lithiation of 2- $n$-alkyl-3H-quinazolin-4-thiones 255 occurred smoothly and rapidly with 2.2 molar equivalents of $n-\mathrm{BuLi}$ at $-78{ }^{\circ} \mathrm{C}$ in THF with no nucleophilic attack at either the thione or the imine group of the quinazolinethione ring to produce dilithium reagent 256 (Scheme 31) as a purple solution. ${ }^{146}$ Reactions of $\mathbf{2 5 6}$ with various electrophiles afforded the corresponding 2-substituted 3H-quinazoline-4-thiones 257-275 (Scheme 31) in excellent yields (Table 17). ${ }^{146}$

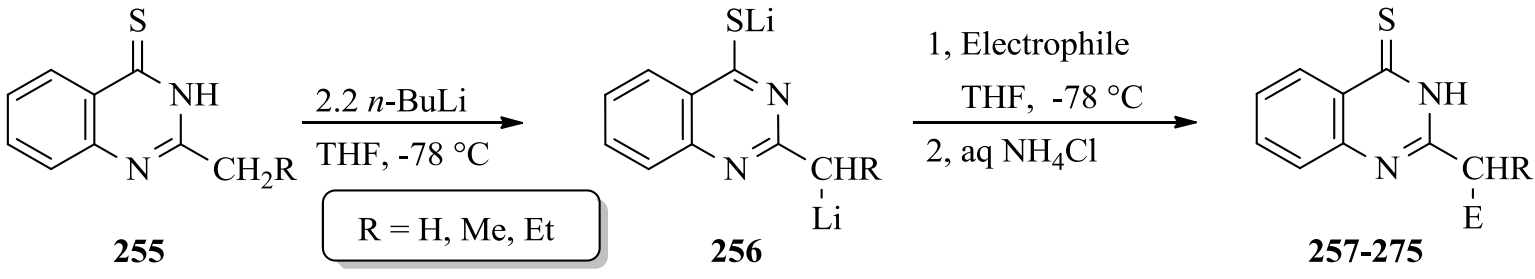

Scheme 31. Lateral lithiation and substitution of 255. 
Table 17. Lithiation and substitution of $\mathbf{2 5 5}$ according to Scheme $31^{146}$

\begin{tabular}{|c|c|c|c|c|}
\hline Product & $\mathrm{R}$ & Electrophile & $\mathrm{E}$ & Yield $(\%)^{\mathrm{a}}$ \\
\hline 257 & $\mathrm{H}$ & $\mathrm{PhCHO}$ & $\mathrm{PhCH}(\mathrm{OH})$ & 87 \\
\hline 258 & $\mathrm{H}$ & $4-\mathrm{MeOC}_{6} \mathrm{H}_{4} \mathrm{CHO}$ & $4-\mathrm{MeOC}_{6} \mathrm{H}_{4} \mathrm{CH}(\mathrm{OH})$ & 89 \\
\hline 259 & $\mathrm{H}$ & $\mathrm{Ph}_{2} \mathrm{CO}$ & $\mathrm{Ph}_{2} \mathrm{C}(\mathrm{OH})$ & 92 \\
\hline 260 & $\mathrm{H}$ & $\mathrm{BuCOMe}$ & $\mathrm{BuC}(\mathrm{OH}) \mathrm{Me}$ & 90 \\
\hline 261 & $\mathrm{H}$ & $\left(\mathrm{CH}_{2}\right)_{5} \mathrm{CO}$ & $\left(\mathrm{CH}_{2}\right)_{5} \mathrm{C}(\mathrm{OH})$ & 91 \\
\hline 262 & $\mathrm{H}$ & PhNCO & $\mathrm{PhNHCO}$ & 84 \\
\hline 263 & $\mathrm{H}$ & $\left(i-\mathrm{Pr}_{2} \mathrm{NCSS}\right)_{2}$ & $i$ - $\mathrm{Pr}_{2} \mathrm{NCSS}$ & 90 \\
\hline 264 & $\mathrm{H}$ & MeI & $\mathrm{Me}$ & 92 \\
\hline 265 & $\mathrm{H}$ & EtI & Et & 90 \\
\hline 266 & $\mathrm{H}$ & $\mathrm{D}_{2} \mathrm{O}$ & $\mathrm{D}$ & 95 \\
\hline 267 & $\mathrm{Me}$ & $\mathrm{PhCHO}$ & $\mathrm{PhCH}(\mathrm{OH})$ & 89 \\
\hline 268 & $\mathrm{Me}$ & $\mathrm{Ph}_{2} \mathrm{CO}$ & $\mathrm{Ph}_{2} \mathrm{C}(\mathrm{OH})$ & 88 \\
\hline 269 & $\mathrm{Me}$ & $\mathrm{BuBr}$ & $\mathrm{Bu}$ & 90 \\
\hline 270 & $\mathrm{Me}$ & MeI & $\mathrm{Me}$ & 95 \\
\hline 271 & $\mathrm{Me}$ & $\mathrm{D}_{2} \mathrm{O}$ & $\mathrm{D}$ & 95 \\
\hline 272 & Et & $4-\mathrm{MeOC}_{6} \mathrm{H}_{4} \mathrm{CHO}$ & $4-\mathrm{MeOC}_{6} \mathrm{H}_{4} \mathrm{CH}(\mathrm{OH})$ & 90 \\
\hline 273 & Et & $\mathrm{Ph}_{2} \mathrm{CO}$ & $\mathrm{Ph}_{2} \mathrm{C}(\mathrm{OH})$ & 95 \\
\hline 274 & Et & $\mathrm{BuBr}$ & $\mathrm{BuBr}$ & 87 \\
\hline 275 & Et & $\mathrm{D}_{2} \mathrm{O}$ & $\mathrm{D}$ & 93 \\
\hline
\end{tabular}

${ }^{\mathrm{a}}$ Yield of isolated product after crystallization from methanol.

${ }^{1} \mathrm{H}$ NMR spectra of compounds $257, \mathbf{2 6 0}, 269$ and 272-274 showed that the two hydrogen atoms of the $\mathrm{CH}_{2}$ group at the 2-position occurred as independent, coupled signals, suggesting that they are diastereotopic. For compound 263, the two isopropyl methyl protons appear as two broad signals and two separated doublets in its ${ }^{1} \mathrm{H}$ NMR spectra recorded at room temperature and $100{ }^{\circ} \mathrm{C}$, respectively. The ${ }^{1} \mathrm{H}$ NMR spectrum of 263 recorded at $150{ }^{\circ} \mathrm{C}$ showed significant line-broadening indicative of the onset of equilibration via rotation about the $\mathrm{C}-\mathrm{N}$ and $\mathrm{C}-\mathrm{S}$ bonds, thereby confirming the origin of the non-equivalence of the two isopropyl methyl protons. The NMR spectra of compounds 267 and 272 show the expected presence of two racemic diastereoisomers.

\subsection{Lateral lithiation of 4-substituted 2-n-alkylquinazolines}

Lateral lithiation of 2-n-alkylquinazolines 276, substituted in the 4-position by a methoxy or methanethiyl group, have been achieved by the use of 1.1 molar equivalents of $n$-BuLi at $-78{ }^{\circ} \mathrm{C}$ in anhydrous THF under nitrogen to produce the corresponding lithium reagents 277 (Scheme 32) as purple solutions. ${ }^{147}$ Reactions of $\mathbf{2 7 7}$ with various electrophiles afforded the corresponding 2-substituted derivatives 278-308 (Scheme 32) in high yields (Tables 18 and 19)..$^{147}$ 


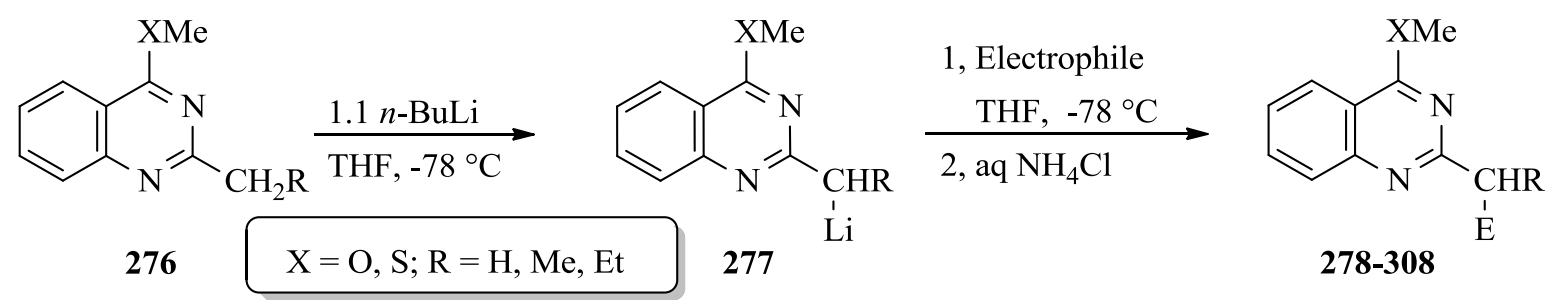

Scheme 32. Lateral lithiation and substitution of $\mathbf{2 7 6 .}$

In some cases, a nucleophilic addition of $n$-BuLi took place at the $\mathrm{C}=\mathrm{N}$ bond via $1,2-$ or 3,4addition to give side products 309-311 and 313 (Figure 6). ${ }^{147}$ Side product 312 (Figure 6) was formed due to 1,2-addition of $n$-BuLi followed by methylation at $\mathrm{N}-1$ with iodomethane. Side product 314 (Figure 6) was obtained as a result of addition of $n$-BuLi at the imine bond at position 4 , followed by elimination of the methoxy group and further addition of $n$-BuLi.

Table 18. Lithiation and substitution of $276(X=S)$ according to Scheme $32^{147}$

\begin{tabular}{ccccc}
\hline Product & $\mathrm{R}$ & Electrophile & $\mathrm{E}$ & Yield $(\%)^{\mathrm{a}}$ \\
\hline $\mathbf{2 7 8}$ & $\mathrm{H}$ & $\mathrm{PhCHO}$ & $\mathrm{PhCH}(\mathrm{OH})$ & 83 \\
$\mathbf{2 7 9}$ & $\mathrm{H}$ & $4-\mathrm{MeOC} \mathrm{H}_{4} \mathrm{CHO}$ & $4-\mathrm{MeOC} \mathrm{H}_{4} \mathrm{CH}(\mathrm{OH})$ & 86 \\
$\mathbf{2 8 0}$ & $\mathrm{H}$ & $\mathrm{PhCOMe}$ & $\mathrm{PhC}(\mathrm{OH}) \mathrm{Me}$ & 85 \\
$\mathbf{2 8 1}$ & $\mathrm{H}$ & $\mathrm{BuCOMe}$ & $\mathrm{BuC}(\mathrm{OH}) \mathrm{Me}$ & 84 \\
$\mathbf{2 8 2}$ & $\mathrm{H}$ & $\mathrm{Ph}_{2} \mathrm{CO}$ & $\mathrm{Ph}_{2} \mathrm{C}(\mathrm{OH})$ & 90 \\
$\mathbf{2 8 3}$ & $\mathrm{H}$ & $\left(\mathrm{CH}_{2}\right)_{5} \mathrm{CO}$ & $\left(\mathrm{CH}_{2}\right)_{5} \mathrm{C}(\mathrm{OH})$ & 85 \\
$\mathbf{2 8 4}$ & $\mathrm{H}$ & $\mathrm{MeI}$ & $\mathrm{Me}$ & 91 \\
$\mathbf{2 8 5}$ & $\mathrm{H}$ & $\mathrm{EtI}$ & $\mathrm{Et}$ & 88 \\
$\mathbf{2 8 6}$ & $\mathrm{H}$ & $\mathrm{D}_{2} \mathrm{O}$ & $\mathrm{D}$ & 89 \\
$\mathbf{2 8 7}$ & $\mathrm{Me}$ & $\mathrm{PhCHO}^{28}$ & $\mathrm{PhCH}(\mathrm{OH})$ & $80^{\mathrm{b}}$ \\
$\mathbf{2 8 8}$ & $\mathrm{Me}$ & $\mathrm{Ph}_{2} \mathrm{CO}$ & $\mathrm{Ph}_{2} \mathrm{C}(\mathrm{OH})$ & $81^{\mathrm{b}}$ \\
$\mathbf{2 8 9}$ & $\mathrm{Me}$ & $\mathrm{MeI}$ & $\mathrm{Me}$ & $82^{\mathrm{b}}$ \\
$\mathbf{2 9 1}$ & $\mathrm{Me}$ & $\mathrm{D}_{2} \mathrm{O}$ & $\mathrm{D}$ & $85^{\mathrm{b}}$ \\
$\mathbf{2 9 2}$ & $\mathrm{Et}$ & $4-\mathrm{MeOC}_{6} \mathrm{H}_{4} \mathrm{CHO}$ & $4-\mathrm{MeCC}_{6} \mathrm{H}_{4} \mathrm{CH}(\mathrm{OH})$ & $78^{\mathrm{c}}$ \\
$\mathbf{2 9 3}$ & $\mathrm{Et}$ & $\left(\mathrm{CH}_{2}\right)_{5} \mathrm{CO}$ & $\left(\mathrm{CH}_{2}\right)_{5} \mathrm{C}(\mathrm{OH})$ & $79^{\mathrm{c}}$ \\
\hline
\end{tabular}

a

${ }^{\mathrm{a}}$ Yield of isolated product after purification by column chromatography.

${ }^{\mathrm{b}}$ Compound 309 (Figure 6) was obtained in 3-5\% yield.

${ }^{\mathrm{c}}$ Compound 310 (Figure 6) was obtained in $4-7 \%$ yield. 
Table 19. Lithiation and substitution of $\mathbf{2 7 6}(\mathrm{X}=\mathrm{O})$ according to Scheme $32^{147}$

\begin{tabular}{ccccc}
\hline Product & $\mathrm{R}$ & Electrophile & $\mathrm{E}$ & ${\text { Yield }(\%)^{\mathrm{a}}}^{\mathrm{a}}$ \\
\hline $\mathbf{2 9 4}$ & $\mathrm{H}$ & $\mathrm{PhCHO}$ & $\mathrm{PhCH} \mathrm{OH})$ & 80 \\
$\mathbf{2 9 5}$ & $\mathrm{H}$ & $4-\mathrm{MeOC}_{6} \mathrm{H}_{4} \mathrm{CHO}$ & $4-\mathrm{MeOC}_{6} \mathrm{H}_{4} \mathrm{CH}(\mathrm{OH})$ & 82 \\
$\mathbf{2 9 6}$ & $\mathrm{H}$ & $\mathrm{PhCOMe}$ & $\mathrm{PhC}(\mathrm{OH}) \mathrm{Me}$ & 85 \\
$\mathbf{2 9 7}$ & $\mathrm{H}$ & $\mathrm{BuCOMe}$ & $\mathrm{BuC}(\mathrm{OH}) \mathrm{Me}$ & 73 \\
$\mathbf{2 9 8}$ & $\mathrm{H}$ & $\mathrm{Ph}_{2} \mathrm{CO}$ & $\mathrm{Ph}_{2} \mathrm{C}(\mathrm{OH})$ & 81 \\
$\mathbf{2 9 9}$ & $\mathrm{H}$ & $\left(\mathrm{CH}_{2}\right)_{5} \mathrm{CO}$ & $\left(\mathrm{CH}_{2}\right)_{5} \mathrm{C}(\mathrm{OH})$ & 75 \\
$\mathbf{3 0 0}$ & $\mathrm{H}$ & $\mathrm{MeI}$ & $\mathrm{Me}$ & 90 \\
$\mathbf{3 0 1}$ & $\mathrm{H}$ & $\mathrm{EtI}$ & $\mathrm{Et}$ & 87 \\
$\mathbf{3 0 2}$ & $\mathrm{H}$ & $\mathrm{D}_{2} \mathrm{O}$ & $\mathrm{D}$ & 86 \\
$\mathbf{3 0 3}$ & $\mathrm{Me}$ & $4-\mathrm{MeOC}_{6} \mathrm{H}_{4} \mathrm{CHO}$ & $4-\mathrm{MeOC}_{6} \mathrm{H}_{4} \mathrm{CH}(\mathrm{OH})$ & $71^{\mathrm{b}}$ \\
$\mathbf{3 0 4}$ & $\mathrm{Me}$ & $\mathrm{Ph}_{2} \mathrm{CO}$ & $\mathrm{Ph}_{2} \mathrm{C}(\mathrm{OH})$ & $73^{\mathrm{b}}$ \\
$\mathbf{3 0 5}$ & $\mathrm{Me}$ & $\mathrm{MeI}$ & $\mathrm{Me}$ & $67^{\mathrm{b}, \mathrm{c}}$ \\
$\mathbf{3 0 6}$ & $\mathrm{Me}$ & $\mathrm{D}_{2} \mathrm{O}$ & $\mathrm{D}$ & $76^{\mathrm{b}}$ \\
$\mathbf{3 0 7}$ & $\mathrm{Et}$ & $\mathrm{Ph}_{2} \mathrm{CO}$ & $\mathrm{Ph}_{2} \mathrm{C}(\mathrm{OH})$ & $71^{\mathrm{d,e}}$ \\
$\mathbf{3 0 8}$ & $\mathrm{Et}$ & $\mathrm{D}_{2} \mathrm{O}$ & $\mathrm{D}$ & $79^{\mathrm{d,e}}$ \\
\hline
\end{tabular}

Yield of isolated product after purification by column chromatography.

${ }^{\mathrm{b}}$ Compound 311 (Figure 6) was obtained in 2-3\% yield.

${ }^{\mathrm{c}}$ Compound 312 (Figure 6) was obtained in 3\% yield.

${ }^{\mathrm{d}}$ Compound 313 (Figure 6) was obtained in 3\% yield.

${ }^{\mathrm{e}}$ Compound 314 (Figure 6) was obtained in 1-2\%.<smiles>[R]C1(Br)N=C(C)c2ccccc2N1</smiles>

$309 \mathrm{R}=\mathrm{Et}$ $310 \mathrm{R}=n-\operatorname{Pr}$

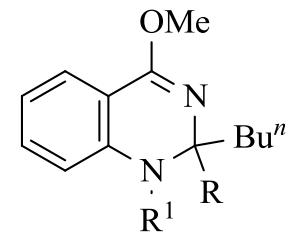

$311 \mathrm{R}=\mathrm{Et}, \mathrm{R}^{1}=\mathrm{H}$

$312 \mathrm{R}=\mathrm{Et}, \mathrm{R}^{1}=\mathrm{Me}$

$313 \mathrm{R}=n-\operatorname{Pr}, \mathrm{R}^{1}=\mathrm{H}$<smiles>CCCC1=Nc2ccccc2C(Br)(Br)N1</smiles>

314

Figure 6. Structures of compounds 309-314.

The ${ }^{1} \mathrm{H}$ NMR spectra of compounds 278-281 and 294-297 showed that the two hydrogen atoms of the $\mathrm{CH}_{2}$ group at $\mathrm{C}-2$ occurred as independent, coupled signals, verifying that they are diastereotopic. $^{147}$ The NMR spectra of compounds 287, 291 and 303 showed the expected presence of two racemic diastereoisomers. In the cases of compounds 287 and 303 the two diastereoisomers were separated by column chromatography. ${ }^{147}$ 


\section{Bromine-Lithium Exchange of 6-Bromo-3H-Quinazolin-4-One}

Bromine-lithium exchange (Scheme 33) has features that make it extremely valuable for the synthesis of organolithium compounds.

$$
\mathrm{R}-\mathrm{Br} \quad+\quad \mathrm{R}^{1}-\mathrm{Li} \quad \mathrm{R}-\mathrm{Li} \quad+\quad \mathrm{R}^{1}-\mathrm{Br}
$$

Scheme 33. Bromine-lithium exchange of bromo compounds using alkyllithium.

The equilibrium lies towards the side having the organolithium compound with the organic group better able to accommodate partial carbanionic character, and it is thus particularly useful for the preparation of aryllithiums by reaction of butyllithium with aryl bromides. ${ }^{14}$ Because bromine-lithium exchange takes place rapidly under mild conditions, potential side-products such as alkylation of the organolithium by the organic halide are not usually troublesome. However, when the desired organolithium reagent is warmed for subsequent reaction it can couple with the alkyl bromide, producing a coupled product $\left(\mathrm{R}-\mathrm{R}^{1}\right) .{ }^{14}$ If alkylation is a problem, it can be minimised by use of two mole equivalents of $t$ - BuLi as alkyllithium. In this case, bromine-lithium exchange is achieved by the first mole equivalent and the second reacts with the $t$-BuBr formed to produce isobutane and isobutene.

Bromine-lithium exchange may involve single electron transfer and radical intermediates (Scheme 34) or proceed through nucleophilic substitution at the bromine via ate complex formation (Scheme 35). ${ }^{12}$ It is believed that alkyl bromides react with alkyllithiums via the radical mechanism, while aryl bromides react via ate complexes as intermediates. ${ }^{12,56}$

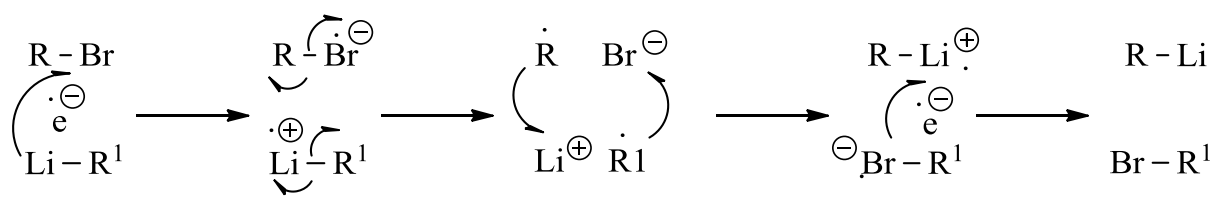

Scheme 34. Bromine-lithium exchange of alkyl bromide via radical intermediate.

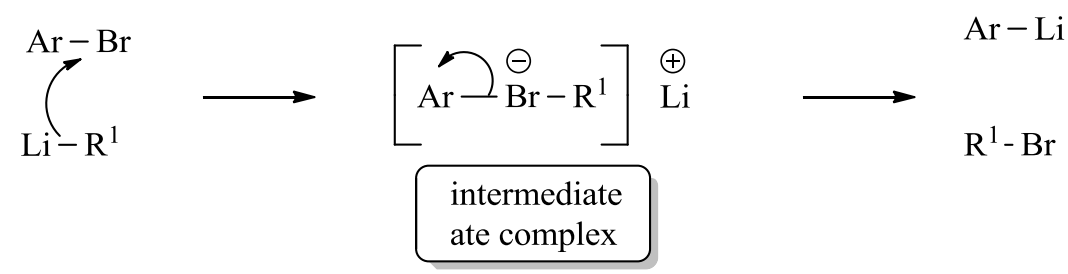

Scheme 35. Bromine-lithium exchange of aryl bromide via ate complex intermediate.

Bromine-lithium exchange of 6-bromo-3H-quinazolin-4-one 315 was successful by the use of MeLi then $t$-BuLi at $-78{ }^{\circ} \mathrm{C}$ in anhydrous THF. ${ }^{148}$ Treatment of 315 with MeLi (1.1 molar 
equivalents) for 5 minutes gave the monolithium reagent 316 by removing the $\mathrm{NH}$ proton, followed by bromine-lithium exchange using $t$-BuLi ( 2.2 molar equivalents) to give the dilithium reagent 317 (Scheme 36) as a yellow solution. Reactions of $\mathbf{3 1 7}$ with a range of electrophiles at $-78{ }^{\circ} \mathrm{C}$ for $2 \mathrm{~h}$ gave the corresponding 6-substituted derivatives 318-326 (Scheme 36) in 81-91\% yields (Table 20). ${ }^{148}$

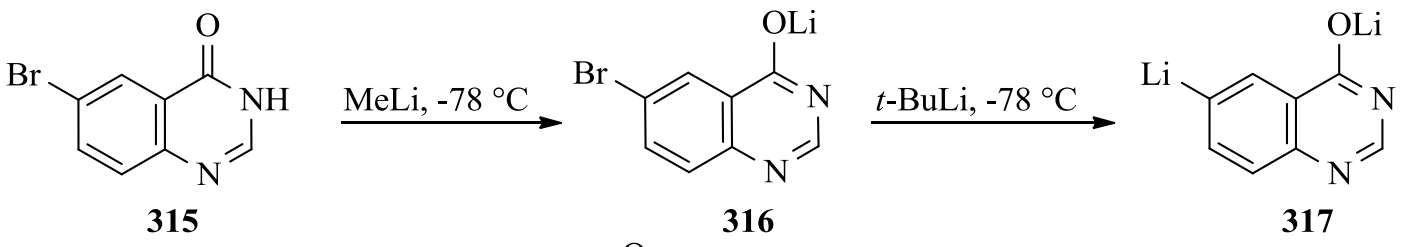

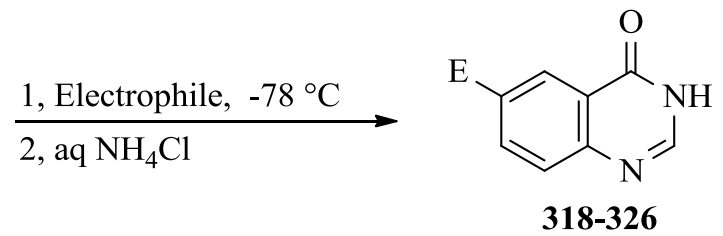

Scheme 36. Bromine-lithium exchange of $\mathbf{3 1 5}$ followed by reactions with electrophiles.

Table 20. Synthesis of 6-substituted $3 H$-quinazolin-4-ones 318-326 according to Scheme $36^{148}$

\begin{tabular}{cccc}
\hline Product & Electrophile & $\mathrm{E}$ & ${\text { Yield }(\%)^{\mathrm{a}}}^{\mathbf{3}}$ \\
$\mathbf{3 1 8}$ & $\mathrm{H}_{2} \mathrm{O}$ & $\mathrm{H}$ & 91 \\
$\mathbf{3 1 9}$ & $\mathrm{EtI}$ & $\mathrm{Et}$ & 84 \\
$\mathbf{3 2 0}$ & $\mathrm{PhCHO}$ & $\mathrm{PhCH}(\mathrm{OH})$ & 81 \\
$\mathbf{3 2 1}$ & $4-\mathrm{MeOC}{ }_{6} \mathrm{H}_{4} \mathrm{CHO}$ & $4-\mathrm{MeOC}_{6} \mathrm{H}_{4} \mathrm{CH}(\mathrm{OH})$ & 83 \\
$\mathbf{3 2 2}$ & $\mathrm{Ph}_{2} \mathrm{CO}$ & $\mathrm{Ph}_{2} \mathrm{C}(\mathrm{OH})$ & 88 \\
$\mathbf{3 2 3}$ & $\mathrm{MeCOBu}_{324}$ & $\mathrm{MeC}(\mathrm{OH}) \mathrm{Bu}$ & 88 \\
$\mathbf{3 2 5}$ & $\left(\mathrm{CH}_{2}\right)_{5} \mathrm{CO}$ & $\left.\mathrm{CH}_{2}\right)_{5} \mathrm{C}(\mathrm{OH})$ & 85 \\
$\mathbf{3 2 6}$ & $\left.\mathrm{PhNCS}^{i} \mathrm{Ph}_{2} \mathrm{NC}(\mathrm{S}) \mathrm{S}\right]_{2}$ & $\mathrm{PhNHCS}_{2}$ & 82 \\
\hline
\end{tabular}

${ }^{\mathrm{a}}$ Yield of isolated product after crystallization from methanol or ethyl acetate.

No $N$-substitution was observed, even when excess iodoethane (2 molar equivalents) as electrophile was used. ${ }^{148}$ In the ${ }^{1} \mathrm{H}$ NMR spectrum of $\mathbf{3 2 6}$ the methyl and $\mathrm{CH}$ protons of the iso-propyl groups appeared as broad signals at room temperature and as doublet and heptet signals, respectively at $80{ }^{\circ} \mathrm{C}$. ${ }^{148}$ This confirms the restricted hindered to rotation about the C-S and $\mathrm{C}-\mathrm{N}$ bonds at room temperature.

Reaction of the dilithium reagent obtained in situ from the bromine lithium exchange of $\mathbf{3 1 5}$ with 1,3 -dibromopropane ( 0.55 mole equivalents) at $-78{ }^{\circ} \mathrm{C}$ gave 6,6 -(propane-1,3-diyl) bis-3Hquinazoline 327 in $71 \%$ yield (Scheme 37$){ }^{148}$ 
<smiles>O=c1[nH]cnc2ccc(Br)cc12</smiles>

$$
\begin{aligned}
& \text { 1, } \mathrm{MeLi},-78^{\circ} \mathrm{C}, \mathrm{THF} \\
& \underset{2, t-\mathrm{BuLi},-78^{\circ} \mathrm{C}, \mathrm{THF}}{\text { 3, } \mathrm{Br}\left(\mathrm{CH}_{2}\right)_{3} \mathrm{Br},-78^{\circ} \mathrm{C}} \\
& \text { 4, aq } \mathrm{NH}_{4} \mathrm{Cl}
\end{aligned}
$$<smiles>O=c1[nH]cnc2ccc(CCCc3ccc4nc[nH]c(=O)c4c3)cc12</smiles>

Scheme 37. Bromine-lithium exchange of $\mathbf{3 1 5}$ followed by reaction with 1,3-dibromopropane.

\section{Addition of Alkyllithiums to Substituted Quinazoline Derivatives}

Nucleophilic addition of alkyllithiums takes place at the imine bond of the quinazoline moiety to produce either 1,2- or 3,4-addition products. However, regioselective lithiation can take place by the use of less nucleophilic lithium reagents.

\subsection{Addition of alkyllithiums to 3-acylamino-3H-quinazolin-4-ones}

It was found that reactions of 3-acylamino-3H-quinazolin-4-ones $\mathbf{5}$ with one molar equivalent of alkyllithiums in $\mathrm{THF}$ at $-78{ }^{\circ} \mathrm{C}$ were very fast and complete within five minutes to give 3-acylamino-2-alkyl-1,2-dihydro-3H-quinazolin-4-ones 329-334 (Scheme 38) in high yields (Table 21). ${ }^{115}$

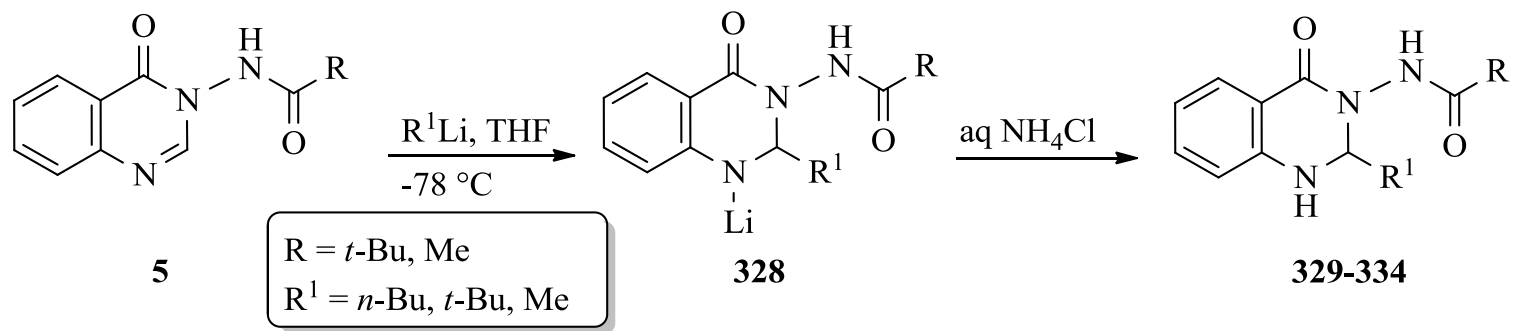

Scheme 38. Addition of alkyllithiums to 3-acylamino-3H-quinazolin-4-ones 5.

Table 21. Synthesis of 3-acylamino-2-alkyl-1,2-dihydro-3H-quinazolin-4-ones 329-334 according to Scheme 38 via 1,2-addition ${ }^{115}$

\begin{tabular}{cccc}
\hline Product & $\mathrm{R}$ & $\mathrm{R}^{1}$ & ${\text { Yield }(\%)^{\mathrm{a}}}^{\mathbf{3} 9}$ \\
$\mathbf{3 3 0}$ & $t-\mathrm{Bu}$ & $n-\mathrm{Bu}$ & 96 \\
$\mathbf{3 3 1}$ & $t-\mathrm{Bu}$ & $t-\mathrm{Bu}$ & 98 \\
$\mathbf{3 3 2}$ & $t-\mathrm{Bu}$ & $\mathrm{Me}$ & 90 \\
$\mathbf{3 3 3}$ & $\mathrm{Me}$ & $n-\mathrm{Bu}$ & 82 \\
$\mathbf{3 3 4}$ & $\mathrm{Me}$ & $t-\mathrm{Bu}$ & 84 \\
& $\mathrm{Me}$ & $\mathrm{Me}$ & 70 \\
\hline \multirow{2}{*}{ Y } &
\end{tabular}


Clearly nucleophilic addition of alkyllithiums at the imine bond of the quinazoline moiety took place to give the corresponding 1,2-addition intermediates 328. Directed lithiation of 3-acylamino-3H-quinazolin-4-ones $\mathbf{5}$, at the 2-position, was achieved by the use of LDA as described in Section 2.1. ${ }^{115}$

\subsection{Addition of alkyllithiums to 6-substituted $3 H$-quinazolin-4-ones}

Regioselective lithiation of 6-methyl-3H-quinazolin-4-ones 335 using alkyllithiums was not successful. ${ }^{148}$ Instead, nucleophilic addition took place at the imine bond to give the corresponding 1,2-addition products. Reactions of $\mathbf{3 3 5}$ with alkyllithiums (one molar equivalent) in THF at $-78{ }^{\circ} \mathrm{C}$ took place within 15 minutes to give 2-alkyl-6-methyl-1,2-dihydro-3Hquinazolin-4-ones 337-339 in high yields via lithium intermediate 336 (Scheme 39). ${ }^{148}$ Lithiation of $\mathbf{3 3 5}$ with a less nucleophilic reagent such as LDA did not take place and only starting material was recovered, indicating that no reaction took place under the conditions tried.
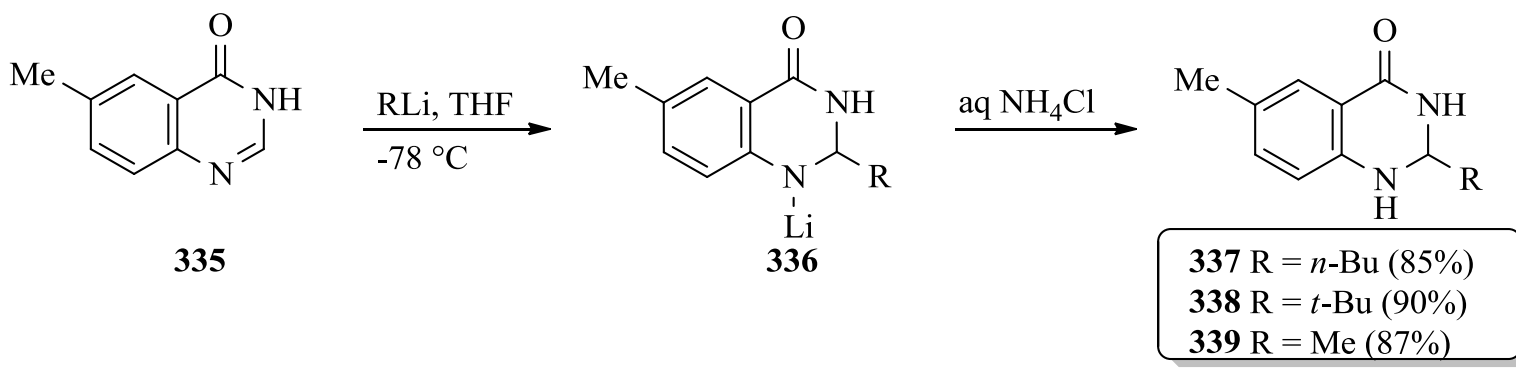

Scheme 39. Addition of alkyllithiums to 6-methyl-3H-quinazolin-4-ones $\mathbf{3 3 5}$.

Reactions of 6-bromo-3H-quinazolin-4-ones $\mathbf{3 1 5}$ with butyllithiums in THF at $-78{ }^{\circ} \mathrm{C}$ followed by reactions with a number of electrophiles (iodoethane, benzaldehyde, $\mathrm{H}_{2} \mathrm{O}$ ) produced low yields of 6-substituted products along with 2-butyl-1,2-dihydro-3 $H$-quinazolin-4-ones. ${ }^{148}$ However, if four molar equivalents of $n$-BuLi or $t$-BuLi were used in THF at $-78{ }^{\circ} \mathrm{C}$ for 30 minutes, 341 and $\mathbf{3 4 2}$ were obtained in 88 and 79\% yields, respectively (Scheme 40). ${ }^{148}$ The author suggested that compound $\mathbf{3 4 0}$ was formed as an intermediate. Compound $\mathbf{3 1 5}$ was successfully converted into the 6-lithio derivative using a combination of $\mathrm{MeLi}$ and $t$-BuLi in THF at $-78^{\circ} \mathrm{C}$ (Section 5)..$^{148}$

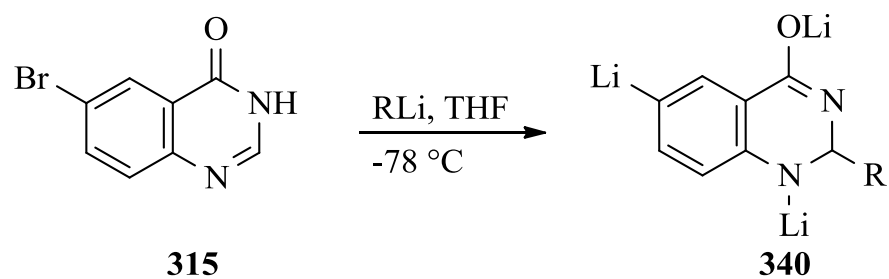<smiles>[R]C1NC(=O)c2ccccc2N1</smiles>

Scheme 40. Addition of butyllithiums to 6-bromo-3H-quinazolin-4-ones 315. 


\subsection{Addition of alkyllithiums to $3 H$-quinazolin-4-thiones}

Reactions of $3 H$-quinazolin-4-thione 343 with two molar equivalents of alkyllithiums in THF at $78 \mathrm{C}$ for $1 \mathrm{~h}$ gave the corresponding 2-alkyl-1,2-dihydro-3H-quinazoline-4-thiones 345-347 in high yields (Scheme 41). ${ }^{149}$ It is believed that such reactions took place through the formation of dilithium reagents 344 .

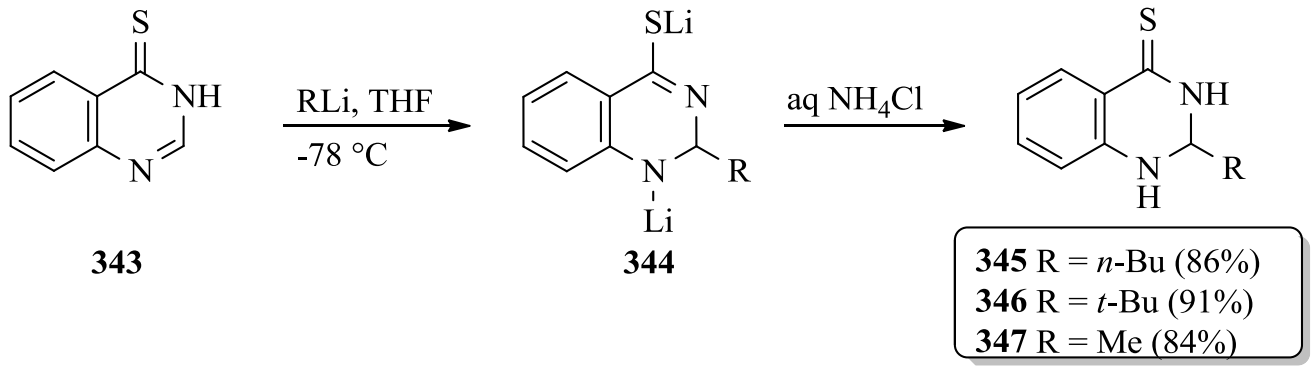

Scheme 41. Addition of alkyllithiums to $3 H$-quinazolin-4-thione 343.

This result contrasts sharply with the situation of $3 \mathrm{H}$-quinazolin-4-one, which does not react at all with alkyllithiums ( $n$-BuLi, $t$-BuLi and $\mathrm{MeLi}$ ) under similar conditions, which is an indication of the important role played by the sulfur atom in this reaction. ${ }^{149}$ The authors suggested that the reason for this difference could be due to the thiolate anion in $\mathbf{3 4 4}$ being less effective at donating negative charge to the ring than its oxygen counterpart. The acquisition of negative charge by the ring would be expected to deactivate the ring towards nucleophilic attack by alkyllithiums. ${ }^{149}$

\subsection{Addition of alkyllithiums to substituted quinazolines}

Reactions of alkyllithiums with various quinazoline derivatives to produce addition products have been reported. ${ }^{121,149-151}$ For example, reactions of 4-substituted quinazolines $\mathbf{1 0 5}$ and 348 with 1.2 molar equivalents of alkyllithiums took place smoothly and cleanly at $-78{ }^{\circ} \mathrm{C}$ in anhydrous THF for $1 \mathrm{~h} .{ }^{149}$ The lithium reagent reagents 349 were presumably obtained as intermediates and after quenching with aqueous ammonium chloride solution gave the corresponding 4-substituted 2-alkyl-1,2-dihydroquinazolines 350-357 (Scheme 42) in high yields (Table 22). ${ }^{149}$ Lithiation of $\mathbf{3 4 8}$ with LDA under similar reaction conditions was not successful. ${ }^{149}$

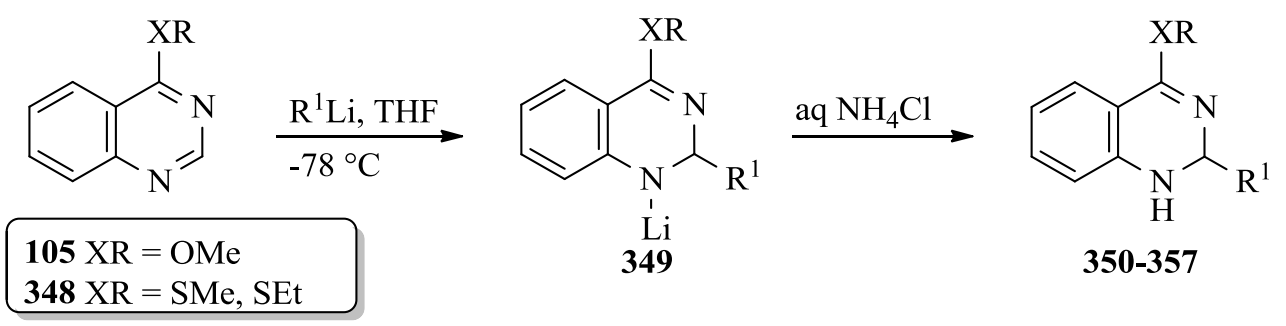

Scheme 42. Addition of alkyllithiums to 4-substituted quinazolines $\mathbf{1 0 5}$ and $\mathbf{3 4 8 .}$ 
Table 22. Synthesis of 4-substituted 2-alkyl-1,2-dihydroquinazolines 350-357 according to Scheme $42^{149}$

\begin{tabular}{ccccc}
\hline Product & $\mathrm{X}$ & $\mathrm{R}$ & $\mathrm{R}^{1}$ & ${\text { Yield }(\%)^{\mathrm{a}}}^{\mathrm{a}}$ \\
\hline $\mathbf{3 5 0}$ & $\mathrm{S}$ & $\mathrm{Me}$ & $n-\mathrm{Bu}$ & 90 \\
$\mathbf{3 5 1}$ & $\mathrm{S}$ & $\mathrm{Me}$ & $t$-Bu & 88 \\
$\mathbf{3 5 2}$ & $\mathrm{S}$ & $\mathrm{Me}$ & $\mathrm{Me}$ & 89 \\
$\mathbf{3 5 3}$ & $\mathrm{S}$ & $\mathrm{Et}$ & $n-\mathrm{Bu}$ & 91 \\
$\mathbf{3 5 4}$ & $\mathrm{S}$ & $\mathrm{Et}$ & $t-\mathrm{Bu}$ & 89 \\
$\mathbf{3 5 5}$ & $\mathrm{O}$ & $\mathrm{Me}$ & $t-\mathrm{Bu}$ & 89 \\
$\mathbf{3 5 6}$ & $\mathrm{O}$ & $\mathrm{Me}$ & 89 \\
$\mathbf{3 5 7}$ & $\mathrm{O}$ & $\mathrm{Me}$ & & 94 \\
\hline
\end{tabular}

${ }^{\mathrm{a}}$ Yield of isolated product after column chromatography.

Reaction of 4-methoxyquinazoline 105 with excess $t$-BuLi gave a mixture of 2-tert-butyl-4methoxy-1,2-dihydroquinazoline $\mathbf{3 5 6}$ and 2-tert-butyl-1,2-dihydro-3H-quinazoline-4-one $\mathbf{3 5 8}$ (Scheme 43) in proportions that depended on the molar equivalents of $t$-BuLi used (Table 23). ${ }^{149}$ Compound 358 was the very product that might have been expected from the reaction of $3 H$-quinazolin-4-one with $t$-BuLi, but, of course, this direct reaction of $3 H$-quinazolin-4-one with $t$-BuLi did not occur. ${ }^{149}$ Compound $\mathbf{3 5 8}$ was obtained due to nucleophilic addition of $t$-BuLi at the 2-position of $\mathbf{1 0 5}$ followed by a $\mathrm{C}=\mathrm{O}$ formation at the 4-position.<smiles>COC1=NC(Cc2ccccc2)Nc2ccccc21</smiles>

Scheme 43. Reaction of 4-methoxyquinazoline 105 with excess $t$-BuLi.

Table 23. Yields of $\mathbf{3 5 6}$ and $\mathbf{3 5 8}$ from reaction of $\mathbf{1 0 5}$ with $t$-BuLi according to Scheme $43^{149}$

\begin{tabular}{ccc}
\hline$t$-BuLi (molar equiv.) & \multicolumn{2}{c}{ Yield $(\%)^{\mathrm{a}}$} \\
\cline { 2 - 4 } & $\mathbf{3 5 6}$ & $\mathbf{3 5 8}$ \\
\hline 1.2 & 89 & - \\
1.4 & 76 & 6 \\
2.0 & 66 & 15 \\
2.4 & 50 & 27 \\
3.0 & 37 & 42 \\
\hline
\end{tabular}

${ }^{\mathrm{a}}$ Yield of isolated product after column chromatography. 
Reactions of 4-substituted 2-phenylquinazoline 359 with one molar equivalent of alkyllithiums ( $n$-BuLi and MeLi) at $-78{ }^{\circ} \mathrm{C}$ in anhydrous THF for one hour gave 4,4-dialkyl-3,4dihydro-2-phenylquinazolines in moderate yields along with significant quantities of starting material 359. ${ }^{149}$ Use of 2.2 molar equivalents of alkyllithium ( $n$-BuLi, $t$-BuLi and MeLi) at $-78{ }^{\circ} \mathrm{C}$ in THF for one hour gave 360-362 (Scheme 44) in high yields (Table 24). ${ }^{121,149}$ Products 360-362 were obtained via 3,4-nucleophilic addition of alkyllithiums followed by displacement of the substituent (SMe, OMe or $\mathrm{O}\left(\mathrm{CH}_{2}\right)_{2} \mathrm{OMe}$ ) as an anion and further addition of alkyllithium. Reaction of 359 with $t$-BuLi gave only a modest yield of product 362 due to formation of byproducts which were not identified. ${ }^{149}$<smiles>Cc1nc(-c2ccccc2)nc2ccccc12</smiles>

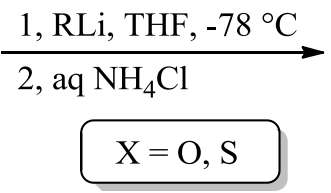<smiles>[R]C1([R])NC(c2ccccc2)=Nc2ccccc21</smiles>

Scheme 44. Addition of alkyllithiums to 4-substituted 2-phenylquinazoline $\mathbf{3 5 9}$.

Table 24. Synthesis of 4,4-dialkyl-3,4-dihydro-2-phenylquinazolines 360-362 according to Scheme $44^{121,149}$

\begin{tabular}{lllll}
\hline Product & $\mathrm{X}$ & $\mathrm{RLi}$ (molar equiv.) & $\mathrm{R}$ & ${\text { Yield }(\%)^{\mathrm{a}}}^{\mathrm{a}}$ \\
\hline $\mathbf{3 6 0}$ & $\mathrm{S}$ & 1.1 & $n-\mathrm{Bu}$ & 49 \\
$\mathbf{3 6 0}$ & $\mathrm{S}$ & 2.2 & $n-\mathrm{Bu}$ & 96 \\
$\mathbf{3 6 0}$ & $\mathrm{O}$ & 1.1 & $n-\mathrm{Bu}$ & 46 \\
$\mathbf{3 6 0}$ & $\mathrm{O}$ & 2.2 & $n-\mathrm{Bu}$ & 88 \\
$\mathbf{3 6 0}$ & $\mathrm{O}\left(\mathrm{CH}_{2}\right)_{2} \mathrm{OMe}$ & 2.2 & $n-\mathrm{Bu}$ & 50 \\
$\mathbf{3 6 1}$ & $\mathrm{S}$ & 1.1 & $\mathrm{Me}$ & 40 \\
$\mathbf{3 6 1}$ & $\mathrm{S}$ & 2.2 & $\mathrm{Me}$ & 81 \\
$\mathbf{3 6 1}$ & $\mathrm{O}$ & 2.2 & $\mathrm{Me}$ & 83 \\
$\mathbf{3 6 2}$ & $\mathrm{S}$ & 2.2 & $t-\mathrm{Bu}$ & 49 \\
$\mathbf{3 6 2}$ & $\mathrm{O}$ & 2.2 & $t-\mathrm{Bu}$ & 49 \\
\hline
\end{tabular}

Yield of isolated product after column chromatography.

Reactions of 2,4-diphenylquinazoline 363 with $\mathrm{MeLi}$ in dry $\mathrm{Et}_{2} \mathrm{O}$ gave 4-methyl-2,4diphenyl-3,4-dihydroquinazoline 364 in 55\% yield (Scheme 45) in which methyllithium was added at the imine bond at the 3-position. ${ }^{150}$ 


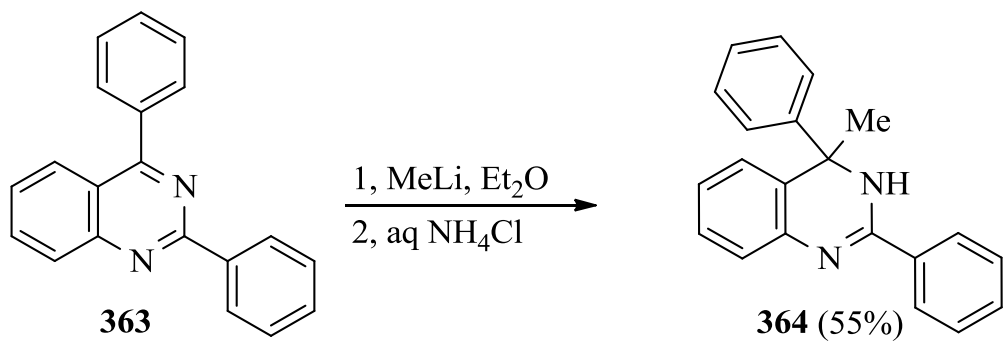

Scheme 45. Synthesis of 4-methyl-2,4-diphenyl-3,4-dihydroquinazoline 364.

\section{Conclusions}

Directed ortho-lithiation of 3-acylamino- $3 \mathrm{H}$-quinazolin-4-ones with LDA at $-78{ }^{\circ} \mathrm{C}$ in anhydrous THF is regiospecific and reactions of the lithium regents obtained with various electrophiles provided access to a broad variety of 2-substituted derivatives in high yields. Similar procedures have been developed for directed lithiation and substitution of 3-aryl-, tert-butylsulfinyl-3Hquinazolin-4-ones, phenylsulfinyl-, chloro- and methoxyquinazolines. Such procedure provided derivatives previously unavailable or that might be difficult to prepare by other means.

Lateral lithiation of 3-acylamino-2- $n$-alkyl-3H-quinazolin-4-ones, at the benzylic position of the $n$-alkyl group, has been achieved by use of $n$-BuLi or LDA at low temperature. Also, lithiation of 3-amino- and 3-methylamino-2- $n$-alkyl-3H-quinazolin-4-ones at low temperature in THF followed by reactions with several electrophiles provides various 2 -substituted derivatives in high yields. The procedure is particularly useful in that there is no protecting group to be removed in another step from the amino function. A similar procedure has been developed for the side-chain lithiation and substitution for 3-aryl- and 3-unsubstituted 2-n-alkyl-3H-quinazolin4-ones and their thione derivatives.

A simple and convenient method for the side-chain substitution of 4-substituted 2-n-alkylquinazolines, with a methoxy or methylthio group at position 4 , has been reported and allows synthesis of various 2-substituted derivatives in high yields. Also, lithiation and substitution of several other quinazoline derivatives have been achieved to provide a range of substituted derivatives.

Bromine-lithium exchange of 6-bromo-3H-quinazolin-4-one has been achieved by the use of $\mathrm{MeLi}$ and $t$-BuLi at $-78{ }^{\circ} \mathrm{C}$ in THF. Reactions of the dilithium reagent thus obtained with electrophiles give the corresponding 6-substituted $3 \mathrm{H}$-quinazolin-4-ones in high yields.

Nucleophilic addition of alkyllithiums to 3-acylamino-3H-quinazolin-4-ones, $3 H$-quinazoline-4-thione and various quinazoline derivatives containing an alkylthio or a methoxy group at C-4 and a phenyl group or a hydrogen at C-2 take place at low temperature. The method provides high yields of various 2-alkyl-1,2-dihydroquinazolines, via 1,2-addition of alkyllithiums, and 4,4-dialkyl-3,4-dihydro-2-phenylquinazolines via 3,4-addition followed by displacement of the substituent (SMe or OMe) at C-4. 


\section{References}

1. Olah, G. A. Friedel-Crafts Chemistry, Wiley-Interscience: New York, 1973.

2. $\quad$ Pearson, D. E.; Buehler, C. A. Synthesis 1972, 533.

3. Florio, S.; Capriati, V.; Salomone, A. Topics in Stereochemistry; Siegel J. S., Ed.; WileyVCH: Weinheim, 2010, Vol 26, Chap. 4.

4. Rathman, T. L.; Bailey, W. F. Org. Process Res. Dev. 2009, 13, 144.

5. Capriati, V.; Florio, S.; Luisi, R. Chem. Rev. 2008, 108, 1918.

6. Chevallier, F.; Mongin, F. Chem. Soc. Rev. 2008, 37, 595.

7. Elschenbroich, C. Organometallics, Wiley-VCH: Weinheim, 2006.

8. Foubelo, F.; Yus, M. Curr. Org. Chem. 2005, 9, 459.

9. Schlosser, M. Angew. Chem. Int. Ed. 2005, 44, 376.

10. Smith, K.; El-Hiti, G. A. Curr. Org. Synth. 2004, 1, 253.

11. Chinchilla, R.; Nájera, C.; Yus, M. Chem. Rev. 2004, 104, 2667.

12. Clayden, J. Organolithiums: Selectivity for Synthesis, Pergamon: Oxford, 2002.

13. Schlosser, M. Organometallics in Synthesis, 2nd ed.; Wiley: Chichester, 2002; pp. 1-352.

14. Wakefield, B. J. In Organolithium Methods; Katritzky, A. R.; Meth-Cohn, O.; Rees, C. W., Ed.; Academic Press: London, 1988.

15. Snieckus, V. Chem. Rev. 1990, 90, 879.

16. Beak, P.; Zajdel, W. J.; Reitz, D. B. Chem. Rev. 1984, 84, 471.

17. Fuhrer, W.; Gschwend, H. W. J. Org. Chem. 1979, 44, 1133.

18. Beak, P.; Snieckus, V. Acc. Chem. Res. 1982, 15, 306.

19. Beak, P.; Musick, T. J.; Chen, C.-W. J. Am. Chem. Soc. 1988, 110, 3538.

20. Smith, K.; Lindsay, C. M.; Morris, I. K.; Matthews, I.; Pritchard, G. J. Sulfur Lett. 1994, 17, 197.

21. Smith, K.; Anderson, D.; Matthews, I. Sulfur Lett. 1995, 18, 79.

22. Godard, A.; Rocca, P.; Pomel, V.; Thomas-dit-Dumont, L.; Rovera, J.-C.; Thaburet, J.-F.; Marsais, F.; Quéguiner, G. J. Organomet. Chem. 1996, 517, 25.

23. Bowles, P.; Clayden, J.; Helliwell, M.; McCarthy, C.; Tomkinson, M.; Westlund, N. J. Chem. Soc., Perkin Trans. 1 1997, 2607.

24. Plé, N.; Turck, A.; Heynderickx, A.; Quéguiner, G. Tetrahedron 1998, 54, 4899.

25. Arzel, E.; Rocca, P.; Marsais, F.; Godard, A.; Quéguiner, G. Tetrahedron 1999, 55, 12149.

26. Choppin, S.; Gros, P.; Fort, Y. Eur. J. Org. Chem. 2001, 603.

27. Turck, A.; Plé, N.; Mongin, F.; Quéguiner, G. Tetrahedron 2001, 57, 4489.

28. Anctil, E. J.-G.; Snieckus, V. J. Organomet. Chem. 2002, 653, 150.

29. Gros, P.; Choppin, S.; Mathieu, J.; Fort, Y. J. Org. Chem. 2002, 67, 234.

30. Whisler, M. C.; MacNeil, S.; Snieckus, V.; Beak, P. Angew. Chem. Int. Ed. 2004, 43, 2206.

31. Florio, S.; Aggarwal, V.; Salomone, A. Org. Lett. 2004, 6, 4191. 
32. Chadwick, S. T.; Ramirez, A.; Gupta, L.; Collum, D. B. J. Am. Chem. Soc. 2007, 129, 2259.

33. Clayden, J.; Turner, H.; Helliwell, M.; Moir, E. J. Org. Chem. 2008, 73, 4415.

34. Lee, W. K.; Park, Y. S.; Beak, P. Acc. Chem. Res. 2009, 42, 224.

35. Hodgson, D. M.; Kloesges, J. Angew. Chem. Int. Ed. 2010, 49, 2900.

36. Fukuda, T.; Ohta, T.; Sudo, E.; Iwao, M. Org. Lett., 2010, 12, 2734.

37. Houlden, C. E.; Lloyd-Jones, G. C.; Booker-Milburn, K. I. Org. Lett. 2010, 12, 3090.

38. Tilly, D.; Fu, J.-M.; Zhao, B.-P.; Alessi, M.; Catanet, A.-S.; Snieckus, V.; Mortier, J. Org. Lett. 2010, 12, 68.

39. Wessels, M.; Mahajan, V.; Bosshammer, S.; Raabe, G.; Gais, H.-J. Eur. J. Org. Chem. 2011, 2431.

40. Skvorcova, A.; Rakovsky, E.; Kozisek, J.; Sebesta, R. J. Organomet. Chem. 2011, 696, 2600.

41. (a) Snieckus, V. Beilstein J. Org. Chem. 2011, 7, 1215. (b) Cho, I.; Meimetis, L.; Belding, L.; Katz, M. J.; Dudding, T.; Britton, R. Beilstein J. Org. Chem. 2011, 7, 1315. (c) Page, A.; Clayden, J. Beilstein J. Org. Chem. 2011, 7, 1327.

42. (a) Schmid, M.; Waldner, B.; Schnürch, M.; Mihovilovic, M. D.; Stanetty, P. Tetrahedron 2011, 67, 2895. (b) Degennaro, L.; Mansueto, R.; Carenza, E.; Rizzi, R.; Florio, S.; Pratt, L. M.; Luisi, R. Chem. Eur. J. 2011, 17, 4992. (c) de Ceglie, M. C.; Musio, B.; Affortunato, F.; Moliterni, A.; Altomare, A.; Florio, S.; Luisi, R. Chem. Eur. J. 2011, 17, 286.

43. (a) Clayton, J.; Clayden, J. Tetrahedron Lett. 2011, 52, 2436. (b) Clayden, J.; MacLellan, P. Beilstein J. Org. Chem. 2011, 7, 582. (c) Campbell, S. A.; Donnard, M.; Haywood, J.; McPartlin, M.; Vincent, M. A.; Hillier, I. H.; Clayden, J.; Wheatley, A. E. H. Chem. Eur. J. 2011, 17, 8078 .

44. (a) Ibrahim, N.; Chevot, F.; Legraverend, M. Tetrahedron Lett. 2011, 52, 305. (b) Solovyev, A.; Lacôte, E.; Curran, D. P. Org. Lett. 2011, 13, 6042.

45. Clayden, J.; Turner, H.; Pickworth, M.; Adler, T. Org. Lett. 2005, 7, 3147.

46. Clayden, J.; Dufour, J. Tetrahedron Lett. 2006, 47, 6945.

47. Comoy, C.; Banaszak, E.; Fort, Y. Tetrahedron 2006, 62, 6036.

48. Luisi, R.; Capriati, V.; Florio, S.; Musio, B. Org. Lett. 2007, 9, 1263.

49. Burgos, P. O.; Fernández, I.; Iglesias, M. J.; García-Granda, S.; Ortiz, F. L. Org. Lett. 2008, 10, 537.

50. Castanet, A.-S.; Tilly, D.; Véron, J.-B.; Samanta, S. S.; De, A.; Ganguly, T.; Mortier, J. Tetrahedron 2008, 64, 3331.

51. Clayden, J.; Hennecke, U. Org. Lett. 2008, 10, 3567.

52. McLaughlin, M.; Marcantonio, K.; Chen, C.; Davies, I. W. J. Org. Chem. 2008, 73, 4309.

53. Capriati, V.; Florio, S.; Luisi, R.; Mazzanti, A.; Musio, B. J. Org. Chem. 2008, 73, 3197.

54. Affortunato, F.; Florio, S.; Luisi, R.; Musio B. J. Org. Chem. 2008, 73, 9214.

55. Michon, C.; Murai, M.; Nakatsu, M.; Uenishi, J.; Uemura M. Tetrahedron 2009, 65, 752. 
56. Quéguiner, G.; Marsais, F.; Snieckus, V.; Epsztajn, J. Advances in Heterocyclic Chemistry: Directed Metallation of $\pi$-deficient Azaaromatics Katritzky, A. R. Ed.; Academic Press: London, 1991, pp 187-304.

57. Clayden, J.; Hamilton, S. D.; Mohammed, R. T. Org. Lett. 2005, 7, 3673.

58. Macklin, T.; Ang, P.; Blanchet, J.; Metallinos, C.; Snieckus, V. J. Org. Chem. 2007, 72, 3199.

59. Sánchez, J. D.; Cledera, P.; Perumal, S.; Avendaño, C.; Menéndez, J. C. Synlett 2007, 2805.

60. Chau, N. T. T.; Nguyen, T. H.; Castanet, A.-S.; Nguyen, K. P. P.; Mortier, J. Tetrahedron 2008, 64, 10552.

61. Sahin, A.; Cakmak, O.; Demirtas, I.; Okten, S.; Tutar, A. Tetrahedron 2008, 64, 10068.

$62 . \quad$ - $\quad$-Ortiz, F.; Cuevas, C.; Serrano-

Ruiz, M. Org. Lett. 2008, 10, 3981.

63. ， S.; Zajac K. J. Org. Chem. 2008, 73, 7785.

64. Shibasaki, T.; Ooishi, T.; Yamanouchi, N.; Murafuji, T.; Kurotobi, K.; Sugihara, Y. J. Org. Chem. 2008, 73, 7971.

65. van der Stoel, R. E.; van der Plas, H. C. J. Chem. Soc., Perkin Trans. 1 1979, 2393.

66. van der Stoel, R. E.; van der Plas, H. C. Recl. Trav. Chim. Pays-Bas 1978, 97, 116.

67. Ziegler, K.; Zeiser, H. Ann. 1931, 485, 174.

68. Ziegler, K.; Zeiser, H. Ber. 1930, 63, 1874.

69. Marsais, F.; Bouley, E.; Quéguiner, G. J. Organomet. Chem. 1979, 171, 273.

70. Godard, A.; Turck, A.; Plé, N.; Marsais, F.; Quéguiner, G. Trends Heterocycl. Chem. 1993, 3, 19 .

71. Jen, T.; Dienel, B.; Dowalo, F.; Van Hoeven, H.; Bender, P.; Loev, B. J. Med. Chem. 1973, 16, 633.

72. Marsham, P. R.; Hughes, L. R.; Jackman, A. L.; Hayter, A. J.; Oldfield, J.; Wardleworth, J. M.; Bishop, J. A. M.; O’Connor, B. M.; Calvert, A. H. J. Med. Chem. 1991, 34, 1594.

73. Dempcy, R. O.; Skibo, E. B. Bioorg. Med. Chem. 1993, 1, 39.

74. Hennequin, L. F.; Boyle, F. T.; Wardleworth, J. M.; Marsham, P. R.; Kimbell, R.; Juckman, A. L. J. Med. Chem. 1996, 39, 695.

75. Hour, M.-J.; Huang, L.-J.; Kuo, S.-C.; Xia, Y.; Bastow, K.; Nakanishi, Y.; Hamel, E.; Lee, K.-H. J. Med. Chem. 2000, 43, 4479.

76. Alagarsamy, V.; Murugananthan, G.; Venkateshperumal, R. Biol. Pharm. Bull. 2003, 26, 1711.

77. Alagarsamy, V. Pharmazie 2004, 59, 753.

78. Alagarsamy, V.; Giridhar, R.; Yadav, M. R. Bioorg. Med. Chem. Lett. 2005, 15, 1877.

79. Alagarsamy, V.; Giridhar, R.; Yadav, M. R. J. Pharm. Pharmacol. 2006, 58, 1249.

80. Aagarsamy, V.; Pathak, U. S. Bioorg. Med. Chem. 2007, 15, 3457.

81. Aagarsamy, V.; Shankar, D.; Murugan, M.; Siddiqui, A. A.; Rajesh, R. Arch. Pharm. 2007, 340, 41 . 
82. Shaban, M. A. E.; Taha, M. A. M.; Sharshira, E. M. Advances in Heterocyclic Chemistry: Synthesis and Biological Activities of Condensed Heterocyclo[n,m-a,b or c]quinazolines, Katritzky, A. R. Ed.; Academic Press: New York, 1991, Vol. 52; pp. 1-303.

83. Horton, D. A.; Bourne, G. T.; Smythe, M. L. Chem. Rev. 2003, 103, 893.

84. Michael, J. P. Nat. Prod. Rep. 2005, 22, 627

85. Eguchi, S. Top. Heterocyl. Chem. 2006, 6, 113.

86. Shawali, A. S.; Farghaly, T. A. Arkivoc 2008,(i), 18.

87. Abdel-Megeed, M. F.; Aly, Y. L.; Saleh, M. A.; Abdo, I. M.; El-Hiti, G. A.; Smith, K. Sulfur Lett. 1995, 19, 129.

88. Abdo, M. A.; Abdel-Megeed, M. F.; Saleh, M. A.; El-Hiti, G. A. Pol. J. Chem. 1995, 69, 583.

89. Abdel-Megeed, M. F.; Saleh, M. A.; Abdo, M. A.; El-Hiti, G. A. Collect. Czech. Chem. Commun. 1995, 60, 1016.

90. Saleh, M. A.; Abdo, M. A.; Abdel-Megeed, M. F.; El-Hiti, G. A. Indian J. Chem. 1996, $35 B, 147$.

91. El-Hiti, G. A. Bull. Chem. Soc., Jpn. 1997, 70, 2209.

92. Abdo, M. A.; Zeid, I. F.; El-Hiti, G. A.; Mahmoud, O. E. Indian J. Chem. 1999, 38B, 850.

93. Abdel-Megeed, M. F.; El-Hiti, G. A.; Saleh, M. A.; Abdo, M. A.; Awadalla, S. E. Rev. Roum. Chim. 1999, 44, 67.

94. El-Hiti, G. A.; Abdel-Megeed, M. F.; Mahmoud, Y. A.-G. Indian J. Chem. 2000, 39B, 368.

95. Abdel-Megeed, M. F.; El-Hiti, G. A.; Abdo, M. A.; Saleh, M. A. Rev. Roum. Chim. 2000, $45,545$.

96. El-Hiti, G. A. Alex. J. Pharm. Sci. 2000, 14, 37.

97. El-Hiti, G. A.; Abdel-Megeed, M. F.; Zied,T. M. Indian J. Chem. 2002, 41B, 1519.

98. El-Brollosy, N. R.; Abdel-Megeed, M. F.; El-Hiti, G. A.; Genady, A. R. Afinidad 2003, 60, 199.

99. El-Hiti, G. A.; Abdel-Megeed, M. F. Heterocycles 2005, 65, 3007.

100. Abdel-Megeed, M. F.; Azaam, M. M.; El-Hiti, G. A. Monatsh. Chem. 2007, 138, 153

101. El-Hiti, G. A.; Hussain, A.; Hegazy, A. S.; Alotaibi, M. H. J. Sulfur Chem. 2011, 32, 361.

102. Smith, K.; El-Hiti, G. A.; Hamilton, A. J. Chem. Soc., Perkin Trans. 1 1998, 4041.

103. Smith, K.; El-Hiti, G. A.; Pritchard, G. J.; Hamilton, A. J. Chem. Soc., Perkin Trans. 1 1999, 2299.

104. Smith, K.; El-Hiti, G. A.; Shukla, A. P. J. Chem. Soc., Perkin Trans. 1 1999, 2305.

105. Smith, K.; El-Hiti, G. A.; Hawes, A. C. Synlett 1999, 945.

106. Smith, K.; El-Hiti, G. A.; Hawes, A. C. Synthesis 2003, 2047.

107. Smith, K.; El-Hiti, G. A.; Mahgoub, S. A. Synthesis 2003, 2345.

108. El-Hiti, G. A. Synthesis 2003, 2799.

109. Smith, K.; El-Hiti, G. A.; Hegazy, A. S. Synlett 2009, 2242. 
110. Smith, K.; El-Hiti, G. A.; Hegazy, A. S.; Fekri, A.; Kariuki, B. M. Arkivoc 2009, (xiv), 266.

111. Smith, K.; El-Hiti, G. A.; Hegazy, A. S. Chem. Commun. 2010, 46, 2790.

112. Smith, K.; El-Hiti, G. A.; Hegazy, A. S. Synthesis 2010, 1371.

113. Smith, K.; El-Hiti, G. A.; Hegazy, A. S. Kariuki, B. Beilstein J. Org. Chem. 2011, 7, 1219-1227.

114. El-Hiti, G. A. Heterocycles 2000, 53, 1839.

115. Smith, K.; El-Hiti, G. A.; Abdel-Megeed, M. F.; Abdo, M. A. J. Org. Chem. 1996, 61, 647.

116. Smith, K.; El-Hiti, G. A.; Abdel-Megeed, M. F. Russ. J. Org. Chem. 2003, 39, 430.

117. Dai, X.; Virgil, S. Tetrahedron: Asymmetry 1999, 10, 25.

118. Potewar, T. M.; Ingale, S. A.; Srinivasan, K. V. Arkivoc 2008, (xiv), 100.

119. Chapoulaud, V. G.; Salliot, I.; Plé, N.; Turck, A.; Quéguiner, G. Tetrahedron 1999, 55, 5389.

120. Le Fur, N.; Mojovic, L.; Plé, N.; Turck, A.; Marsais, F. Tetrahedron 2005, 61, 8924.

121. Plé, N.; Turck, A.; Chapoulaud, V. G.; Quéguiner, G. Tetrahedron 1997, 53, 2871.

122. Chapoulaud, V. G.; Plé, N.; Turck, A.; Quéguiner, G. Tetrahedron 2000, 56, 5499.

123. Colwell, W. T.; Yamamoto, K.; Christie, P.; Henry, D. W. Synth. Commun. 1972, 2, 109.

124. Woodbury, R. P.; Rathke, M. W. J. Org. Chem. 1977, 42, 1688.

125. Busch, A.; Chapoulaud, V. G.; Audoux, J.; Plé, N.; Turck, A. Tetrahedron 2004, 60, 5373.

126. Mhaske, S. B.; Argade, N. P. J. Org. Chem. 2004, 69, 4563.

127. Smith, K.; El-Hiti, G. A.; Abdo, M. A.; Abdel-Megeed, M. F. J. Chem. Soc., Perkin Trans. 1 1995, 1029.

128. Smith, K.; El-Hiti, G. A.; Abdel-Megeed, M. F. Synthesis 2004, 2121.

129. Atkinson, R. S. In Comprehensive Organic Chemistry, Eds. Barton, D. H. R.; Ollis, W. D. Pergamon: Oxford, 1978, Vol. 2, p. 225.

130. Shvo, Y. in The Chemistry of the Hydrazo, Azo and Azoxy Groups, Ed. S. Patai, Interscience: New York, 1975, Part 2.

131. Moriarty, R. M.; Murphy, M. R.; Druck, S. J.; May, L. Tetrahedron Lett. 1967, 8, 1603.

132. Dewar, M. J. S.; Jennings, W. B. J. Am. Chem. Soc. 1969, 91, 3655.

133. Anderson, J. E.; Griffith, D. L.; Roberts, J. D. J. Am. Chem. Soc. 1969, 91, 6371.

134. Fletcher, J. R.; Sutherland, I. O. J. Chem. Soc., Chem. Commun. 1970, 687.

134. Dewar, M. J. S.; Jennings, W. B. J. Am. Chem. Soc. 1973, 95, 1562.

135. Mannschreck, A.; Koelle, U. Tetrahedron Lett. 1967, 8, 863.

136. Marullo, N. P.; Mayfield, C. B.; Wagener, E. M. J. Am. Chem. Soc. 1968, 90, 510.

137. Tolles, W. M.; Moore, D. W.; Thun, W. E. J. Am. Chem. Soc. 1966, 88, 3476.

138. El-Hiti, G. A. Spectrosc. Lett. 1999, 32, 671.

139. Atkinson, R. S.; Barker, E.; Price, C. J.; Russell, D. R. J. Chem. Soc., Chem. Commun. 1994, 1159. 
140. Smith, K.; El-Hiti, G. A.; Abdel-Megeed, M. F.; Abdo, M. A. J. Org. Chem. 1996, 61, 656.

141. Rathman, T. L.; Sleevi, M. C.; Krafft, M. E.; Wolfe, J. F. J. Org. Chem. 1980, 45, 2169.

142. Dai, X.; Virgil, S. Tetrahedron Lett. 1999, 40, 1245.

143. Smith, K.; El-Hiti, G. A.; Abdel-Megeed, M. F.; Abdo, M. A. Collect. Czech. Chem. Commun. 1999, 64, 515.

144. Murray, T. P.; Hay, J. V.; Portlock, D. E.; Wolfe, J. F. J. Org. Chem. 1974, 39, 595.

145. Philipova, I.; Dobrikov, G.; Krumova, K.; Kaneti, J. J. Heterocycl. Chem. 2006, 43, 1057.

146. El-Hiti, G. A. Synthesis, 2004, 363.

147. Smith, K.; El-Hiti, G. A.; Hegazy, A. S. Synthesis 2005, 2951.

148. El-Hiti, G. A. Monatsh. Chem. 2004, 135, 323.

149. Smith, K.; El-Hiti, G. A.; Hegazy, A. S. J. Sulfur Chem. 2005, 26, 121.

150. Smith, J. G.; Sheepy, J. M. J. Heterocycl Chem. 1975, 12, 231.

151. Briggs, T. F.; Winemiller, M. D.; Collum, D. B.; Parsons, R. L.; Davulcu, A. H.; Harris, G. D.; Fortunak, J. M.; Confalone, P. N. J. Am. Chem. Soc. 2004, 126, 5427.

\section{Authors' Biographies}

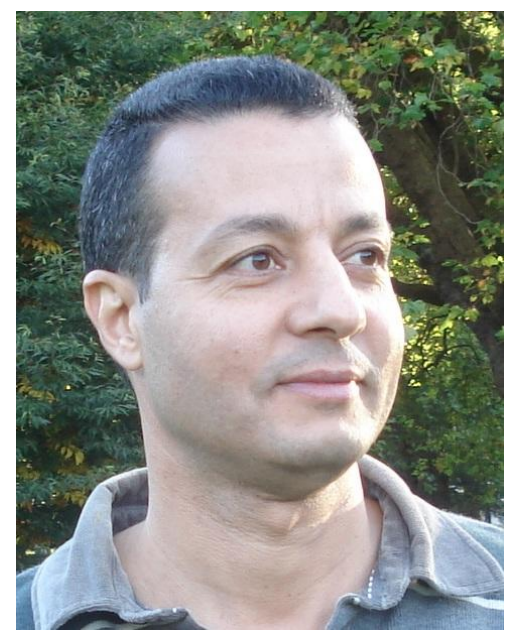

Professor Gamal A. El-Hiti

Gamal A. El-Hiti received his B.Sc. and M.Sc. degrees from Tanta University, Egypt in 1986 and 1990, respectively. He received his Ph.D. degree from Tanta University in 1996 including two years at Swansea University, UK. He first joined Keith Smith's research group in 1993 while enrolled for a PhD in Egypt. He was awarded a scholarship to allow him to spend two years in the UK to take advantage of the availability of advanced facilities. Keith and he were able to elaborate various quinazolinones into more complex derivatives and this formed the basis of his $\mathrm{PhD}$ thesis when he returned to Egypt to resume his job as a lecturer in 1996. As soon as his 
university would permit it, Keith invited him back to the UK as a postdoctoral researcher and found support funding. Keith did the same on two more occasions and the latter has been continuous for the last 11 years. During these periods he has formed a very close working relationship with Keith's group and they have collaborated extensively. Together they have over 50 joint publications, including ones in all of the major areas of research in which Keith's group is involved and several reviews. They have recently started up a spin-out company to commercialise some of their innovations in the area of catalysis. He has acted as the Technical Director for the Company since August 2006. His research interests are primarily in the development of novel organic synthetic methods, especially ones that are "greener" than traditionally, and synthesis of compounds with interesting properties. Particular current research projects involve use of zeolites and solid-supported reagents and catalysts to gain selectivity in organic reactions; lithiation reactions, which they have used to devise novel heterocyclic ring syntheses and to introduce selectivity into aromatic and heterocyclic substitution reactions; heterocyclic chemistry and design and synthesis of novel compounds with interesting chemiluminescent or other photoactive properties. He is currently a Professor of Organic Chemistry since 2006 at Tanta University, Faculty of Science, Department of Chemistry, Egypt (on sabbatical leave to the UK).

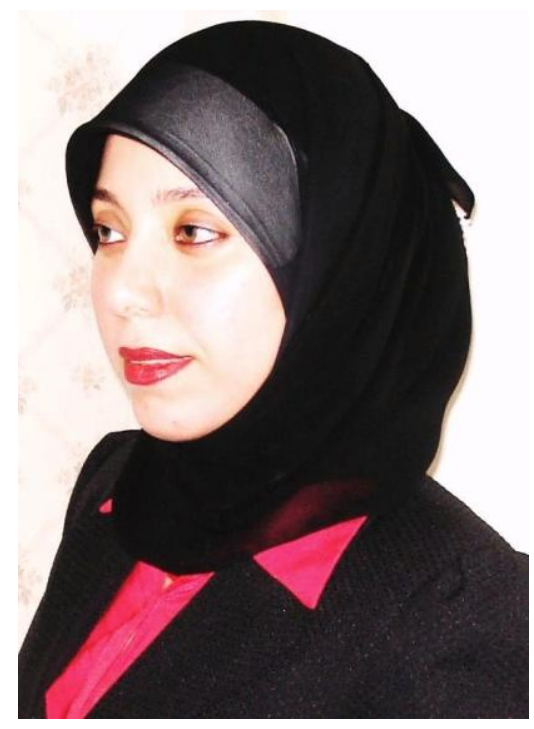

\section{Dr Amany S. Hegazy}

Amany S. Hegazy received her B.Sc. degree in Chemistry from Tanta University, Egypt. She received her MPhil degree from Swansea University, UK in 2006 and her Ph.D. degree from Cardiff University, UK in 2009. She carried out her postgraduate studies under the supervision of Professor Keith Smith. Her research focused on the green synthetic methods of heterocycles and aromatics via use of organolithium reagents as intermediates. 


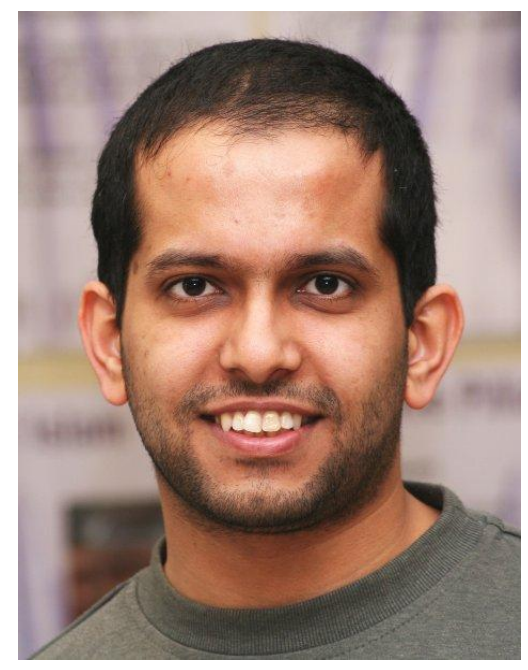

\section{Dr Mohammad H. Alotaibi}

Mohammed Hayal Alotaibi was born in Saudi Arabia. He received his B.Sc. degree in Chemistry from King Saud University, Saudi Arabia. He received his Ph.D. degree from Cardiff University, UK in 2008 under the supervision of Professor Keith Smith. His research focused on the use of zeolites as catalysts in nitration of aromatic compounds. Currently, he is working in Forensic Laboratories in Riyadh, Saudi Arabia.

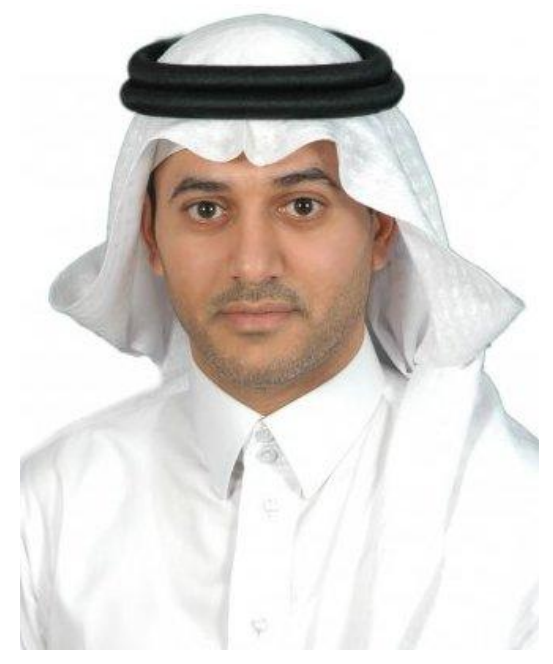

\section{Dr Mansour D. Ajarim}

Mansour D. Ajarm was born in Saudi Arabia. He received his B.Sc. degree in Pharmacy from King Saud University, Saudi Arabia. He received his Ph.D. degree from Cardiff University, UK in 2010 under the supervision of Professor Keith Smith. His research focused on the use of zeolites as catalysts in nitration of aromatic compounds. Currently, he is working in Forensic Laboratories in Riyadh, Saudi Arabia. 